Article

\title{
Dynamic Linkages among Economic Development, Energy Consumption, Environment and Health Sustainable in EU and Non-EU Countries
}

\author{
Yongqi Feng ${ }^{1}$, Xinye Yu ${ }^{1}$, Yung-ho Chiu ${ }^{2} \mathbb{C}$ and Tzu-Han Chang ${ }^{2, *}$ \\ 1 School of Economics, Jilin University, No. 2699, Qianjin Street, Changchun 130012, China; \\ fyqjldx@jlu.edu.cn (Y.F.); yuxinye1024@163.com (X.Y.) \\ 2 Department of Economics, Soochow University, No. 56, Kueiyang St., Sec. 1, Taipei 100, Taiwan; \\ echiu@scu.edu.tw \\ * Correspondence: angleyc06@gmail.com; Tel.: +886-2-23111531 (ext. 5201); Fax: +886-2-27976015
}

Received: 16 October 2019; Accepted: 4 November 2019; Published: 6 November 2019

\begin{abstract}
There is a close and important relationship between environmental pollution and public health, and environmental pollution has an important impact on the public health. This study employed the two-stage meta-frontier dynamic network data envelopment analysis (TMDN-DEA) model to explore the environment pollution effects from energy consumption on the mortality of children and adult, tuberculosis rate, survival rate and health expenditure efficiencies in $28 \mathrm{EU}$ countries and 53 non-EU countries from 2010 to 2014. We calculated the overall efficiency scores and the technology gap ratios of each EU and non-EU countries and the efficiencies of input and output variables in the production and health stage. The average overall efficiencies each year in EU countries are higher than in the non-EU countries. But EU countries have higher energy efficiency than non-EU countries, and non-EU countries have higher health efficiency than EU countries. The health expenditure efficiencies in the EU countries are obviously lower than those in non-EU countries. The renewable energy efficiencies are obviously higher than the non-renewable energy efficiencies; PM2.5 efficiencies are obviously higher than the $\mathrm{CO}_{2}$ efficiencies and the children's mortality rate efficiencies are higher than the adult's mortality rate efficiencies for EU countries and non-EU countries. The government management in the EU and non-EU countries should be strengthened to reduce the air pollutant and carbon dioxide emissions and raise energy transformation to the clean energy in renewable energy and improve health efficiencies in medical and health care field.
\end{abstract}

Keywords: energy efficiency; health efficiency; EU countries; meta-frontier dynamic network DEA

\section{Introduction}

The European Union (EU) is an important intergovernmental economic union and produced $21.54 \%$ GDP of the world in 2018 [1]. The EU is actively exploring the issue of climate change and the environmental pollution. The EU has set a target of $20 \%$ renewable energy in total energy use in 2020. There are $11 \mathrm{EU}$ members that have reached their 2020 targets, with Sweden's 54.5\% target being the highest share of renewable energy in total energy in the EU, with Luxembourg's $6.4 \%$ and the Netherland's $6.6 \%$ target are the lowest. France's goal of achieving its 2020 renewable energy share is $23 \%$, but it has not yet been achieved [2].

The other countries also attach great importance to energy efficiency and environmental issues. As early as 1997, the United Nations Framework Convention on Climate Change adopted the Kyoto Protocol at the third Conference of States Parties. In November 2017, the 23rd Conference of the Parties to the United Nations Framework Convention on Climate Change was held in Bonn, Germany. The conference formulated the implementation guidelines for the Paris Agreement. The main content 
includes controlling the global temperature to within 2 degrees Celsius before the industrial revolution and reducing greenhouse gas emissions in stages.

There are some input-output relationship and influence mechanism among energy, environment pollution, and health, as shown in the Figure 1. When energy consumption and labor and capital input contribute to economic growth, they can result in environmental pollution, for example, carbon emissions and air pollution. The carbon emissions and air pollution have very strong impact on the respiratory, heart, and brain functions and lead to some serious disease, although government and society will have a lot of relational health expenditure for the health treatment.

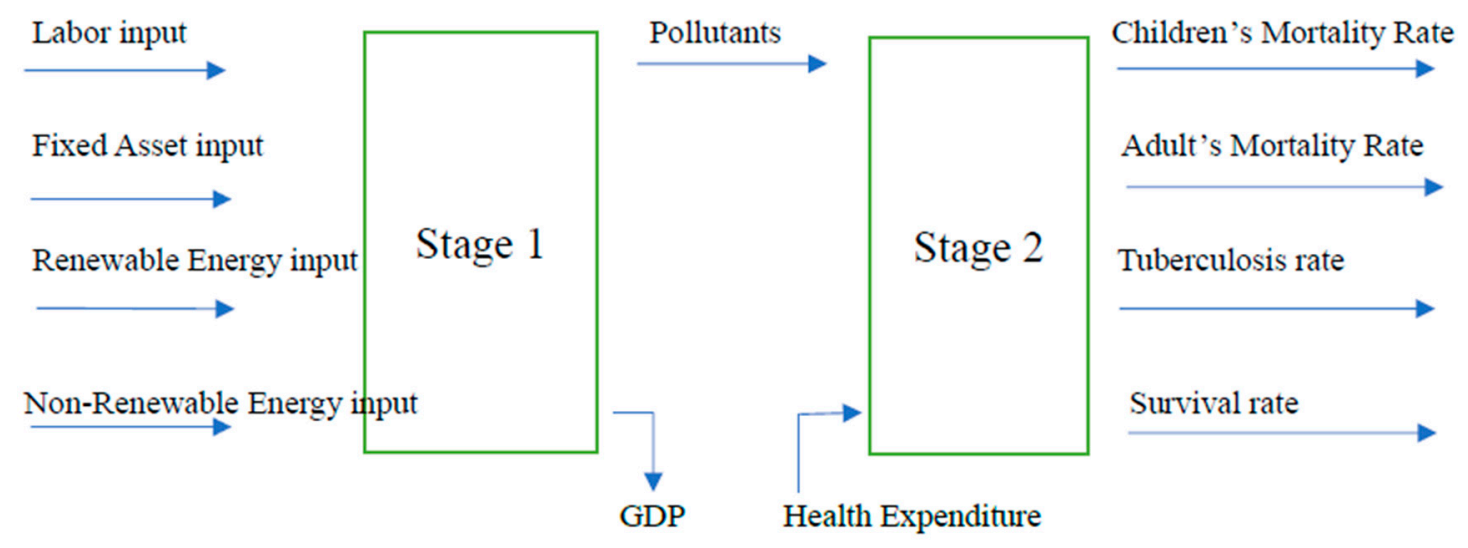

Figure 1. Process of inputs and outputs in production and health treatment stage.

Based on such influence and transmission mechanism, this study employed a two-stage meta-frontier dynamic network data envelopment analysis (TMDN-DEA) model to explore the environment pollution effects from energy consumption on the mortality of children and adult, tuberculosis rate, survival rate and health expenditure efficiencies in EU and non-EU countries. This research analyzes the energy and health efficiencies in EU and non-EU countries. The first stage is the production stage and we can learn the energy efficiencies from this stage. The second stage is the health treatment stage and we can learn the health efficiencies from this stage.

This study has two main contributions. First, energy, environment, and health are included in one model to comprehensively explore energy and health efficiency of EU countries and non-EU countries taking comparative analysis. Second, this study divides the energy into the renewable energy and the non-renewable energy and divides the mortality rate into children's mortality rate and adult's mortality rate.

The remainder of this article is organized as follows: the second section gives the literature review, the third section introduces the research model and method, the fourth section gives the empirical study results, and the fifth section presents the conclusions and implications.

\section{Literature Review}

There have been many studies on energy environment and health issues, mainly from two independent directions of environment and health. The first area has been focusing on energy and environmental efficiency analyses. The second area is about the impact on human health from environmental pollution.

Energy and environmental topics have long been analyzed by many scholars from the perspectives of economy, energy, pollution, and governance. With regard to the importance of energy and environmental issues, many scholars have also done a lot of research on this topic. Among them, some scholars use the data envelopment analysis (DEA) method to study the energy efficiency [3-14]. The EU countries are also the important research objects of energy and environmental issues [15-19]. These studies focus on the relationship between energy and environment, the impact on environment from the economy, energy, pollution. One reason why energy and environmental issues are widely 
concerned is because it is closely related to our health. Some scholars also studied the relationship between environmental pollution and human health [20-33]. As we know, the EU countries are also the regions in the world that have invested heavily in health care. In the case of environmental pollution inevitably, what is the effect of health input in EU? This is a question worth considering and studying. However, there has been less research jointly focusing on the associations between energy, environment pollution, and health.

Sueyoshi and Mika [3] proposed a non-oriented DEA model to study the gas $\left(\mathrm{NO}_{\mathrm{X}}\right)$ caused by acid rain in the United States Clean Air Act (CAA). This study found that the environmental law is effective for the emission control of $\mathrm{SO}_{2}$ and $\mathrm{NO}_{X}$ produced by coal-fired power plants in the United States. Liou and $\mathrm{Wu}$ [4] used the DEA model to analyze the global energy efficiency and carbon dioxide emissions and to seek pure technical efficiency to improve $\mathrm{CO}_{2}$ emissions control scale efficiency for utilization in developing countries. Choi et al. [5] used the SBM-DEA method to explore China's energy efficiency and found that carbon dioxide efficiency was seriously poor. Zhang and Choi [6] used SBM-DEA to study the environmental efficiency of various provinces in China. The results showed that most provinces had low energy efficiency and there were significant differences in environmental efficiency between regions. Yang and Wang [7] used the DEA model to collect data from various provinces in China from 2000 to 2007 to explore the energy efficiency on environment. The results showed that the energy efficiency on environment in China is low and economic output and carbon dioxide emissions need to be improved. Zhao et al. [8] believed that the power industry is China's largest source of air pollution, accounting for $40 \%$ of carbon dioxide emissions and $60 \%$ of sulfur dioxide emissions. The Chinese power plant industry must implement environmental regulations to improve the efficiency and environmental performance; moreover, reducing carbon dioxide has a significant impact. Yao et al. [9] collected panel data of China's provincial industrial sector from 1998 to 2011, using the meta-frontier non-radial Malmquist $\mathrm{CO}_{2}$ emission performance index (MNMCPI) indicator to analyze the changes in China's carbon dioxide emission efficiency and its driving force. The empirical results showed that the average annual growth rate of $\mathrm{CO}_{2}$ emissions from China's provincial industrial sector was 5.53\% from 1998 to 2011 . The average carbon dioxide emissions of the industrial sector in the eastern, central, and western regions decreased in turn, and the annual growth rate of MNMCPI's efficiency (EC) indicators increased. The rate was $2.297 \%$, and the carbon dioxide emission efficiency change (EC) in 21 provinces showed an upward trend. Wang et al. [10] explored China's energy efficiency from 2008 to 2012 by non-oriented DEA model. The results showed that Shandong and Hainan were effective in terms of natural and management disposition, while other provinces are likely to improve their energy and environmental performance. Many provincial industrial sectors should strive to reduce pollution through technology investments. In addition, the average under natural and managerial disposability in western China was highest, followed by eastern China, and central China. Qin et al. [11] used data envelopment analysis to assess the energy efficiency of China's coastal areas from 2000 to 2012. The empirical results showed that the economic development level of China's coastal areas was positively correlated with energy efficiency performance, except for Beijing and Hainan. Sağlam [12] explored the energy efficiency of the 39 states of the United States using a two-stage DEA model. The results showed that more than half of the states had high energy efficiency and can effectively reduce carbon dioxide emissions. Feng et al. [13] analyzed China's total carbon dioxide emissions efficiency and carbon dioxide emission reduction potential. The results showed that because of structural inefficiency, technical and management efficiency is also low, China's carbon dioxide emission efficiency was relatively low, and the government should rely on industry structural adjustments to reduce regional technology gaps to reduce carbon dioxide emissions. Bi et al. [14] used the SBM-DEA model to explore the relationship between fossil fuel consumption and China's thermal power generation environmental regulation. The results showed that energy efficiency and environmental efficiency were relatively low, and the energy and environmental efficiency scores of different provinces varied widely. Mingxing Sun et al. [15] studied the pulp industry in many countries and regions, through meta-analysis, and concluded that the main factor affecting the greenhouse gas 
emissions in papermaking process is energy using. In pulping process, the energy utilization rate is $62 \%$, and the greenhouse gas emissions are $45 \%$. Shihong Zeng et al. [16] used VAR model to study the dynamic relationship among emission limitation price, economic development, and energy price in Beijing. Mojie Li et al. [17] summarized the development policy of China's non-ferrous metal industry when they studied China's non-ferrous metal industry. The carbon emissions of non-ferrous metal industry are analyzed by bottom-up model. Shihong Zeng et al. [18] also studied the efficiency of investment in China's new energy industry and found that the investment efficiency of new energy enterprises is affected by both macroeconomic conditions and specific characteristics of enterprises by DEA model analysis.

There are also many studies to take European countries as research objects on energy environment and health issues. Bampatsou et al. [19] used the DEA model to explore the energy efficiency of the 15 EU countries from 1980 to 2008. The results showed that the input of nuclear energy as a mixture of energy had a negative impact on the efficiency of countries and also caused serious environmental problems. Cucchiella et al. [20] used the DEA model to explore the energy and environmental efficiency of EU countries. Research and results showed that the energy and environmental efficiency of the EU countries were low, and countries with poor efficiency can influence energy efficiency through potential emissions and energy consumption reduction. Gomez-Calvet [21] used the directional distance function to analyze the energy efficiency of $25 \mathrm{EU}$ countries. The results show that there are significant efficiency differences between EU countries, especially in the latest EU countries. The energy efficiency is poor and environmental policies need to be formulated to reduce $\mathrm{CO}_{2}$ emissions. Dumana and Kasman [22] used the parametric hyperbolic distance function to study the environmental efficiency of EU Member States during the period 1990-2011. The results showed that the environmental technical efficiency scores among EU countries were different, compared with new members and candidate countries. The first 15 countries in EU had greater potential to reduce carbon dioxide emissions while increasing gross domestic product and reducing energy use. Cecchini et al. [23] used the DEA model to explore the energy efficiency of European livestock industry. The results showed that the improvement of European livestock technology had a significant relationship to reduce carbon dioxide emissions. Suzuki and Nijkamp [24] found EU countries appear to exhibit generally a higher energy-environment-economic efficiency than APEC and ASEAN countries by distance friction minimization (DFM) model. Moutinho et al. [25] used both data envelopment analysis and stochastic frontier analysis to compute the agriculture technical efficiency scores of 27 European countries. Reinhard et al. [26] estimated the comprehensive environmental efficiency measures for Dutch dairy farms by stochastic frontier analysis (SFA) and data envelopment analysis (DEA). Robaina-Alves and Moutinho V. [27] identified the effects the intensity of GHG emissions (El) in agriculture and analyzed which of them has more importance in determining the intensity of emissions in agriculture for European countries. Toma et al. [28] examined the agricultural efficiency of EU countries through a bootstrap-data envelopment analysis (DEA) approach and indicated that most of the oldest EU countries had a more efficient and optimized crop production process in terms of resource savings and output maximization. Vlontzos G., Niavis S., Manos B. [29] evaluated the energy and environmental efficiency of the primary sectors of the EU Member State countries based on a non-radial data envelopment analysis (DEA) model and found a series of eastern European countries achieve low efficiency scores. Some scholars have also explored the impact of exposure to environmental pollution on human health. Cohen et al. [30] found that the mortality from PM2.5 increased from 35 million in 1990 to 42 million in 2015. Wang [31] explored the impact of energy consumption emissions from various industries and regions in China on population health hazards. Studies have shown that increased PM10 and $\mathrm{SO}_{2}$ emissions can significantly harm population health. Fischer et al. [32] explored long-term exposure to air pollution and urban studies and concluded that long-term exposure to PM10 and $\mathrm{NO}_{2}$ in the Netherlands over 30 years of age is associated with increased mortality. Yang et al. [33] studied the effects of long-term exposure to ambient air pollution on hypertension and analyzed 24,845 adults (aged 18-74 years) in three cities in Northeast China in 2009. The results showed that pollutants 
and hypertension were positively correlated in the early stage and also had significant effects on systolic and diastolic blood pressure, and long-term exposure to environmental air pollution is associated with pre-hypertension and high blood pressure, especially in women and the elderly. Li et al. [34] explored air pollution and health problems in various provinces in China. The research showed that PM2.5 emissions and economic losses caused different health problems. It was also found that Beijing's energy consumption and PM2.5 emissions both showed rapid growth and mortality. The economic losses were the biggest, and the government should reduce PM2.5 emissions to reduce public health impacts. Liu et al. [35] used the LEAP (long-range energy alternative planning system) model to analyze the carbon dioxide emissions and health problems caused by energy consumption from 2010 to 2015 . The results showed that acute bronchitis was the most serious affected by PM10 pollution, and policy measures should be taken to reduce carbon dioxide and pollutant emissions. Dauch et al. [36] explored the relationship between short-term exposure to air pollution and lung function in northern French cities, and the relationship between non-respiratory adult non-respiratory diseases in middle-aged non-smoking adults. The results showed that $\mathrm{O}_{3}$ increased in the blood. There was a significant relationship between the increase in eosinophil count, and the clinical decline in healthy lung function and the increase in inflammatory markers in French residents with short-term exposure to air pollution. Carlton et al. [37] assessed the relationship between air exchange rates and respiratory health in a multi-ethnic population living in low-income urban households, using a structured questionnaire from a standard instrument to estimate the annual average air exchange rate (AAER) for each family. Correlation with respiratory symptoms had shown that residents in families with higher AAERs were more likely to suffer from chronic cough, asthma, and asthma-like symptoms. Shen et al. [38] used the total air quality index (AQI) and the health risk air quality index (HAQI) to assess health risks. The results showed that current AQI systems may significantly underestimate the health risks of air pollution based on HAQI results. The public may need stricter health protection measures to ensure safety. Ljungman et al. [39] used linear regression to study the relationship between long-term and short-term air pollution exposure and arterial stiffness. The results showed that long-term exposure to PM2.5 was not associated with arterial stiffness but was positively correlated with life near the main road, indicating that the contaminant mixture was very close to the main road, not PM2.5, which may affect the arterial stiffness. In addition, short-term air pollution exposure was not associated with higher arterial stiffness. Torres et al. [40] studied exposure and its adverse health effects. The results showed that sulfur dioxide and fine particles in the Alentejo and Lisbon metropolitan areas showed an increasing trend, with deaths in the northern regions and metropolitan areas. The rate had also increased significantly. Chen et al. [41] explored the effects of short-term ambient air pollutants on the health and lung function of primary school children. The results showed a significant relationship with measured lung function decline in the exposure environment of PM2.5 and PM10. Knibbs et al. [42] studied the children's health from 7-year-old to 11-year-old in 12 cities in Australia, using satellite land-use regression (LUR) models to estimate $\mathrm{NO}_{2}$ concentrations in schools and households for each child. Among the 2630 children, the prevalence of asthma was currently $14.9 \%$. According to estimates, there was an impact between exposure to outdoor $\mathrm{NO}_{2}$ and adverse respiratory health on the children in Australia. Roberts et al. [43] explored the problems between air pollutants in urban areas and mental health in childhood and adolescence and found that children under the age of 12 years old exposed to air pollution were not significantly associated with mental health problems. Zaman et al. [44] explored the relationship between energy consumption, environment, health, and its impact on the economic growth of BRICS countries in BRICS countries (Brazil, Russia, India, China and South Africa) during 1975. The results showed that the environment variables have had a detrimental effect on the economic growth of BRICS countries, while energy had significantly increased the economic growth of countries, and it had also been found that health expenditures and infrastructure need to be appropriate for health issues related to fertility and mortality in BRICS countries.

The studies on the energy and environmental efficiency focus on the many objects, such as fossil fuel consumption, $\mathrm{CO}_{2}, \mathrm{SO}_{2}$, and $\mathrm{NO}_{\mathrm{X}}$ emissions in some countries or in various provinces/states in 
some one countries. Their research yielded essentially the same results that energy and environmental efficiencies is low, especially for developing area. The studies on the energy and environmental efficiency in EU countries focus on the efficiency of nuclear energy, the energy efficiency of European livestock industry, the efficiency differences among EU countries (Gomez-Calvet; Dumana and Kasman), the GHG emissions (El) and the agricultural efficiency. We can learn from their research that the first 15 countries in EU had greater efficiency and energy and environmental efficiency, still have potential to reduce carbon dioxide emissions and so on to improve the energy and environmental efficiency in EU. The studies on the impact of exposure to environmental pollution on human health mainly focus on the developing countries. For example, China and BRICS countries. Studies have shown that increased PM2.5, PM10, $\mathrm{CO}_{2}$, and $\mathrm{SO}_{2}$ emissions can significantly harm population health.

Table 1 outlines the abovementioned main research topics: energy consumption, environmental pollution, and human health. Although some traditional DEA methods have been employed on above research areas, few studies have explored their relationship among energy, environment, and health efficiency into one model. Thus, this article employed TMDN-DEA model to comprehensively explore energy and health efficiency of EU countries and non-EU countries.

Table 1. Comparison of previous studies and this study.

\begin{tabular}{|c|c|}
\hline Previous Studies & This Study \\
\hline $\begin{array}{l}\text { Research on the energy consumption and } \\
\text { environment efficiency [3-18]. } \\
\text { Research on the EU countries' energy and } \\
\text { environmental issues [19-29]. } \\
\text { Research on the relationship between environmental } \\
\text { pollution on human health [30-44]. }\end{array}$ & $\begin{array}{l}\text { Application of a modified meta dynamic network model with a } \\
\text { production stage to analyze renewable and non-renewable energy } \\
\text { efficiency, and a second health treatment stage focused on health } \\
\text { expenditure and the impact on survival rate of } 65 \text { years old, children } \\
\text { and adult mortality rate in EU countries and non-EU countries. }\end{array}$ \\
\hline
\end{tabular}

Based on the above literature analysis, this paper makes the following research hypotheses:

Hypothesis 1. The average overall efficiency of EU countries is higher than that of non-EU countries.

Hypothesis 2. The overall energy efficiency of EU countries is higher than that of non-EU countries.

Hypothesis 3. The overall health efficiency of EU countries is higher than that of non-EU countries.

Hypothesis 4. In each of the energy efficiencies, EU countries are higher than non-EU countries.

Hypothesis 5. In each of the health efficiencies, EU countries are higher than non-EU countries.

\section{Research Method}

We used TMDN-DEA model to analyze the energy and health efficiencies. TMDN-DEA model in this paper is developed based on SBM dynamic DEA with meta-frontier (MF) and dynamic group boundary model including two stages.

\subsection{SBM Dynamic DEA}

Farrell [45] measured the level of productivity of a decision-making unit by the concept of a boundary production function, which connected the most efficient production points into production boundaries, and the gap between any real production point and production boundary represented the inefficiency of the production point. Based on the concept of "boundary," Charnes et al. [46] put forward the CCR data envelopment analysis model, and Banker et al. [47] extended his hypothesis on scale returns and proposed the BCC model. Since the CCR model and the BCC model measured the radial efficiency, the two models assumed that the inputs and outputs can be adjusted in equal proportions (increase or decrease), and this assumption cannot be applied to some cases. In 2001, 
Tone proposed the slacks-based measure (SBM) model to measure the slack between the input and output items, and used non-radial estimation method to present SBM efficiency with an efficiency value between 0 and 1 . In addition to the CCR, BCC, and SBM models, other scholars also developed the data envelopment analysis. The traditional DEA model converts the efficiency between the two variables through input and output projects, and the conversion process is identified as a "black box." Färe, Grosskopf, and Whittaker [48] proposed network data envelopment analysis (Network DEA) to apply sub-production technology to explore the impact of input allocation and intermediate wealth on the production process.

Tone and Tsutsui [49] proposed a weighted slack-based measures network data envelopment analysis model, with the linkage among the departments of the decision-making unit as the basis for the analysis of the Network DEA model. The Network DEA model improved the traditional DEA's failure to analyze the performance of each department. Tone and Tsutsui [50] extended the SBM model to a dynamic analysis of the slacks-based measure and proposed weighted slack-based measures (Dynamic Network DEA) data envelopment analysis mode, using the linkage between the various departments of the decision-making unit as the basis for the analysis of the Network DEA model, and regarded each department as Sub-DMU (Sub-Decision Making Unit), carry-over activities as linkages, and carry-over activities can be divided into four categories: (1) desirable (good), (2) unwanted (bad), (3) discretionary (changeable), (4) non-discretionary (non-changeable).

\subsection{The Modified Dynamic Network Model}

Since this study considers undesirable output and regional differences in the dynamic network SBM model, we can modify Tone and Tsutsui's [51] dynamic network model and O'Donnell et al. [52] meta-frontier model to be the modified as meta-frontier dynamic network model. The modified meta-frontier dynamic network model is presented as follows.

Suppose there are $n$ number of $D M U s(j=1, \ldots, n)$, with each having $k$ divisions $(k=1, \ldots, K)$, and $T$ time periods $(t=1, \ldots, T)$. Each of the DMUs has an input and output at time period $t$ and a carryover (link) to the next $t+1$ time period.

Set $m_{k}$ and $r_{k}$ to represent the input and output in each division $K$, with $(k, h) i$ representing divisions $k$ to $h ; L_{h k}$ being the $k$ and $h$ division set; the input and output, links and carryover definitions are outlined in the following.

Inputs and Outputs

$X_{i j k}^{t} \in R_{+}\left(i=1, \ldots, m_{k^{\prime}} j=1, \ldots, n ; K=1 \ldots, K ; t=1, \ldots, T\right):$ refers to input $i$ at time period $t$ for $D M U_{j}$ division $k$

$y_{r j k}^{t} \in R_{+}\left(r=1, \ldots, r_{k} ; j=1, \ldots, n ; K=1 \ldots, K ; t=1, \ldots, T\right)$ : refers to output $\mathrm{r}$ in time period $\mathrm{t}$ for $D M U_{j}$ division $k$; if part of the output is not ideal, it is considered an input for the division.

Links

$Z_{j(k h) t}^{t} \in R_{+}\left(j=1 ; \ldots ; n ; l=1 ; . . ; L_{h k} ; t=1 ; \ldots ; T\right) 0$ : refers to the period $\mathrm{t}$ links from $D M U_{j}$ division $k$ to division $h$, with $L_{h k}$ being the number of $k$ to $h$ links.

$\mathrm{Z}_{\mathrm{j}(\mathrm{kh}) \mathrm{t}}^{\mathrm{t}} \in \mathrm{R}_{+}\left(\mathrm{j}=1 ; \ldots ; n ; 1=1 ; \ldots ; \mathrm{L}_{\mathrm{kh}} ; \mathrm{t}=1 ; \ldots ; \mathrm{T}\right)$

Carryovers

$Z_{j k l}^{(t, t+1)} \in R_{+}\left(j=1, \ldots, n ; l=1, . ., L_{k} ; k=1, \ldots k, t=1, \ldots, T-1\right)$ : refers to the carryover of $t$ to the $t+1$ period from $D M U_{j}$ division $k$ to division $h$, with $L_{k}$ being the number of carryover items in division $k$.

\subsection{Meta-Frontier (MF)}

Assuming that all manufacturers $(N)$ are composed of decision units of groups $\left(N=N_{1}+N_{2}\right.$ $\left.+\ldots+N_{g}\right)$ because of different management types, environments, and resources, and $x_{i j}$ and $y_{\mathrm{rj}}$ represent respectively the $i$-th input $(i=1,2, \ldots, m)$, the $r$-th final output $r(r=1,2, \ldots, s)$ in the $j$-th unit $(j=1,2, \ldots, N)$. Under the mate boundary, the decision unit $k$ can choose the final output weight 
that is most favorable to its maximum value, so the efficiency of the decision unit $\mathrm{k}$ under the common boundary can be solved by the following linear programming procedure.

$$
\begin{gathered}
\rho^{*}=\min \frac{\frac{1}{T} \sum_{t=1}^{T} W^{t}\left[1-\frac{1}{m+n i n p u t}\left[\sum_{g=1}^{G} \sum_{i=1}^{m} \frac{S_{i t}^{-}}{X_{\text {iot }}}+\sum_{g=1}^{G} \sum_{r=1}^{\text {ninput }} \frac{S_{r t}^{\text {input }}}{Z_{\text {rot }}^{\text {input }}}\right]\right]}{\frac{1}{T} \sum_{t=1}^{T} W^{t}\left[1+\frac{1}{S_{1}+S_{2}}\left[\sum_{g=1}^{G} \sum_{l=1}^{S 1} \frac{S_{j t}^{+g}}{y_{l o t}^{g}}+\sum_{g=1}^{G} \sum_{l=1}^{S 2} \frac{S_{j t}^{-b}}{y_{l o b}^{b}}\right]\right]} \\
\text { s.t. } \sum_{g=1}^{G} \sum_{\partial=1}^{n} Z_{i j t g} \lambda_{j g}^{t}=\sum_{g=1}^{G} \sum_{\partial=1}^{n} Z_{i j t g} \lambda_{j g}^{t+1}(v i \mid t=1 \cdots i-1)
\end{gathered}
$$

Equation (1) represents the connection equation between term $t$ and $t+1$

$$
\begin{gathered}
X_{i o t}=\sum_{g=1}^{G} \sum_{\partial=1}^{n} X_{i j t g} \lambda_{j g}^{t}+S_{i t}(i=1 \cdots m, t=1 \cdots i) \\
\mathrm{y}_{\text {lot }}=\sum_{g=1}^{G} \sum_{l=1}^{\mathrm{s} 1} y_{\text {lot }}^{+g} \lambda_{\mathrm{j}}^{\mathrm{t}}-\mathrm{s}_{\mathrm{lt}}^{+\mathrm{g}}(1=1, \ldots, \mathrm{s} 1 ; \mathrm{t}=1, \ldots, \mathrm{T}) \\
\mathrm{y}_{\mathrm{lot}}=\sum_{g=1}^{G} \sum_{1=1}^{\mathrm{s} 2} y_{\text {lot }}^{-b} \lambda_{\mathrm{j}}^{\mathrm{t}}-\mathrm{s}_{\mathrm{lt}}^{+b}(1=1, \ldots, \mathrm{s} 2 ; \mathrm{t}=1, \ldots, \mathrm{T}) \\
Z_{\text {iot }}^{\text {good }}=\sum_{g=1}^{G} \sum_{\partial=1}^{n} Z_{i j t g}^{\text {good }} \lambda_{j g}^{t}-S_{i t}^{t} \quad(i=1 \cdots n g o o d ; t=1 \cdots i) \\
\sum_{g=1}^{G} \sum_{\partial=1}^{n} \lambda_{j g}^{t}=1(t=1 \cdots i) \\
\lambda_{j g}^{t} \geq 0, S_{i t}^{-} \geq 0, S_{i t}^{+} \geq 0, S_{i t}^{\text {good }} \geq 0
\end{gathered}
$$

Therefore, we can know the overall technical efficiency (OTE) value of all DMUs under the common boundary model with Equation (2).

\subsection{Dynamic Group Boundary Model}

Assuming that the manufacturer is divided into g groups of decision units, the DMU under each group boundary will choose the most favorable final output weight. Therefore, the efficiency of the DMU under the group boundary will be solved by the following equation:

$$
\begin{gathered}
\theta_{0}^{*}=\min \frac{\frac{1}{T} \sum_{t=1}^{T} W^{t}\left[1-\frac{1}{m+n i n p u t}\left[\sum_{i=1}^{m} \frac{S_{i t}^{-}}{X_{i o t}}+\sum_{r=1}^{\text {ninput }} \frac{S_{r t}^{\text {input }}}{z_{r o t}^{\text {input }}}\right]\right]}{\frac{1}{T} \sum_{t=1}^{T} W^{t}\left[1+\frac{1}{S_{1}+S_{2}}\left[\sum_{l=1}^{S 1} \frac{S_{j t}^{+g}}{y_{l o t}^{g}}+\sum_{l=1}^{S 2} \frac{S_{j t}^{-b}}{y_{l o b}^{b}}\right]\right]} \\
\text { St } \sum_{j=1}^{n} z_{i j t}^{\alpha} \lambda_{j}^{t}=\sum_{j=1}^{n} z_{i j t}^{\alpha} \lambda_{j}^{t+1}(\forall i ; t=1, \ldots, T-1) \\
x_{i o t}=\sum_{j=1}^{n} x_{i j t} \lambda_{j}^{t}+s_{i t}^{-}(i=1, \ldots, m ; t=1, \ldots, T) \\
\mathrm{y}_{\text {lot }}=\sum_{l=1}^{\mathrm{s} 1} y_{l o t}^{+g} \lambda_{\mathrm{j}}^{\mathrm{t}}-\mathrm{s}_{\mathrm{lt}}^{+\mathrm{g}}(1=1, \ldots, \mathrm{s} 1 ; \mathrm{t}=1, \ldots, \mathrm{T}) \\
\mathrm{y}_{\mathrm{lot}}=\sum_{\mathrm{l}=1}^{\mathrm{s} 2} y_{\text {lot }}^{-b} \lambda_{\mathrm{j}}^{\mathrm{t}}-\mathrm{s}_{\mathrm{lt}}^{-b}(1=1, \ldots, \mathrm{s} 2 ; \mathrm{t}=1, \ldots, \mathrm{T}) \\
z_{\text {iot }}^{\text {good }}=\sum_{j=1}^{n} z_{i o t}^{\text {good }} \lambda_{j}^{t}-s_{i t}^{\text {good }}(i=1, \ldots, n g o o d ; t=1, \ldots, T)
\end{gathered}
$$




$$
\begin{gathered}
\sum_{j=1}^{n} \lambda_{j}^{t}=1(t=1, \ldots, T) \\
\lambda_{\mathrm{j}}^{\mathrm{t}} \geq 0, \mathrm{~s}_{\mathrm{it}}^{-} \geq 0, \mathrm{~s}_{\mathrm{it}}^{+} \geq 0, \mathrm{~s}_{\mathrm{it}}^{\text {good }} \geq 0
\end{gathered}
$$

\subsection{Technology Gap Ratio (TGR)}

Since the meta-frontier model contains g groups, the technical efficiency of the meta-frontier (MFE) will be less than the technical efficiency of the group frontier (GFE). The ratio value, called the technology gap ratio (TGR), is shown as:

$$
\mathrm{TGR}=\frac{M F E}{G F E}
$$

\subsection{The Efficiency of Input and Output}

We follow Hu and Wang's [53] total-factor energy efficiency index to overcome any possible bias in the traditional energy efficiency indicator. There are eleven key features of this present study: labor efficiency, non-renewable energy efficiency, renewable energy efficiency, GDP efficiency, health expenditure efficiency, tuberculosis rate efficiency, mortality rate of children efficiency, mortality rate of adult efficiency, survival rate of 65 years old, $\mathrm{CO}_{2}$ efficiency, and PM2.5 efficiency. In our study, "I" represents area and " $\mathrm{t}$ " represents time. The eleven efficiency models are defined in the following:

$$
\begin{aligned}
& \text { Labor efficiency }=\frac{\text { Target Labor input }(i, t)}{\text { Actual Labor input }(i, t)} \\
& \text { Non - renewable Energy efficiency }=\frac{\text { Target non }- \text { renewable energy input }(i, t)}{\text { Actual non - renewable energy input }(i, t)} \\
& \text { Renewable Energy efficiency }=\frac{\text { Target renewable energy input }(i, t)}{\text { Actual renewable energy input }(i, t)} \\
& \text { GDP efficiency }=\frac{\text { Actual GDP desirable output }(i, t)}{\text { Target GDP desirable output }(i, t)} \text { Target } \mathrm{CO}_{2} \text { Undesirable output }(i, t) \\
& \mathrm{CO}_{2} \text { efficiency }=\frac{\text { Actual } \mathrm{CO}_{2} \text { Undesirable output }(i, t)}{\text { Parget Pm2.5 Undesirable output }(i, t)} \\
& \text { Health Expenditure efficiency }
\end{aligned}
$$

$$
\text { Survival rate of } 65 \text { years old efficiency }=\frac{\text { Actual Survival rate of } 65 \text { years old desirable output }(\mathrm{i}, \mathrm{t})}{\text { Target Survival rate of } 65 \text { years old desirable output }(\mathrm{i}, \mathrm{t})}
$$

If the target labor, non-renewable energy efficiency, renewable energy efficiency, and health expenditure input equals the actual input, then the labor, non-renewable energy efficiency, renewable 
energy efficiency, and health expenditure efficiencies equal 1, indicating overall efficiency. If the target labor, non-renewable energy efficiency, renewable energy efficiency, and health expenditure input is less than the actual input, then the labor, non-renewable energy efficiency, renewable energy efficiency, and health expenditure efficiencies are less than 1 , indicating overall inefficiency.

If the target tuberculosis rate efficiency, mortality rate of children efficiency, mortality rate of adult efficiency, $\mathrm{CO}_{2}$, and PM2.5 undesirable outputs equal the actual undesirable outputs, then tuberculosis rate efficiency, mortality rate of children efficiency, mortality rate of adult efficiency, $\mathrm{CO}_{2}$, and PM2.5 efficiencies equal 1 , indicating overall efficiency. If the target tuberculosis rate efficiency, mortality rate of children efficiency, mortality rate of adult efficiency, $\mathrm{CO}_{2}$, and AQI undesirable outputs are less than the actual undesirable outputs, then the tuberculosis rate efficiency, mortality rate of children efficiency, mortality rate of adult efficiency, $\mathrm{CO}_{2}$, and PM2.5 efficiencies are less than 1, indicating overall inefficiency.

If the target GDP and survival rate of 65-years-old desirable output is equal to the actual GDP and survival rate of 65-years-old desirable output, then the GDP and survival rate of 65-years-old efficiency equals 1 , indicating overall efficiency. If the actual GDP and survival rate of 65-years-old desirable output is less than the target GDP desirable output, then the GDP and survival rate of 65-years-old efficiency is less than 1 , indicating overall inefficiency.

Figure 2 reveals the framework of the modified meta dynamic network DEA model of inter-temporal efficiency measurement and variables in this study.

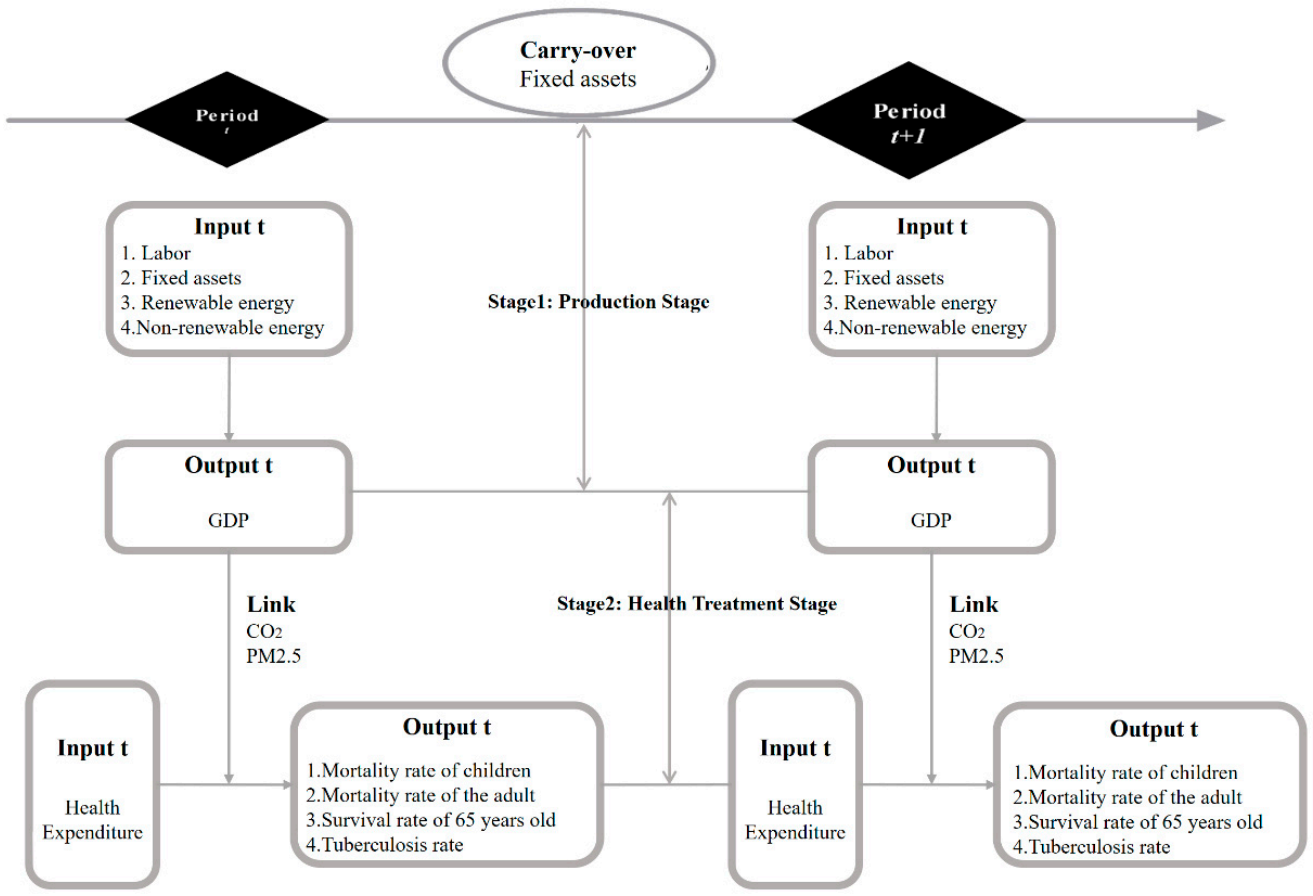

Figure 2. Two-stage meta dynamic network data envelopment analysis (DEA) model.

\section{Empirical Study}

\subsection{Data Sources and Description}

This study compares the energy efficiency and healthy efficiency in EU and non-EU countries from 2010 to 2014. The diseases data are extracted from Global Tuberculosis Control Report (World Health Organization) [54] and the others are from World Development Indicators of the World Bank. Now, there are $28 \mathrm{EU}$ member countries. Based on the data availability, we choose 53 countries as non-EU countries from the other countries. 
In our study, the variables in each stage are showed in the Table 2. The first stage is production stage including three input variables and one output variables. The second stage is the health treatment stage including one input variable and four output variables.

Table 2. Input and output variables.

\begin{tabular}{|c|c|c|c|c|}
\hline Stage & Input Variables & Output Variables & Link & Carry Over \\
\hline \multirow{3}{*}{ Stage 1} & $\begin{array}{l}\text { Labor by million } \\
\text { persons }\end{array}$ & \multirow{3}{*}{$\begin{array}{l}\text { GDP by billion } \\
\text { dollars }\end{array}$} & $\mathrm{CO}_{2}$ by million ton & \multirow{3}{*}{$\begin{array}{l}\text { Fixed assets by } \\
\text { billion dollars }\end{array}$} \\
\hline & $\begin{array}{c}\text { Renewable energy } \\
\text { by mega joule }\end{array}$ & & $\begin{array}{c}\text { PM2.5 by } \\
\text { micrograms per }\end{array}$ & \\
\hline & $\begin{array}{l}\text { Non-renewable } \\
\text { energy by mega } \\
\text { joule }\end{array}$ & & cubic meter & \\
\hline \multirow{4}{*}{ Stage 2} & \multirow[t]{3}{*}{$\begin{array}{c}\text { Health } \\
\text { Expenditure } \\
\text { by billion dollars }\end{array}$} & $\begin{array}{c}\text { Mortality rate of } \\
\text { children (less than } \\
5 \text { years old) by } \\
\text { percent }\end{array}$ & & \\
\hline & & $\begin{array}{c}\text { Mortality rate of } \\
\text { the adult (from } 15 \\
\text { to } 65 \text { years old) by } \\
\text { percent }\end{array}$ & & \\
\hline & & $\begin{array}{c}\text { Survival rate of } 65 \\
\text { years old by } \\
\text { percent }\end{array}$ & & \\
\hline & & $\begin{array}{l}\text { Tuberculosis rate } \\
\text { by \%oo }\end{array}$ & & \\
\hline
\end{tabular}

The first Stage: Production Stage

Input Variables:

Labor: The numbers of employees in each country by the end of each year. Unit: Million person.

Renewable energy: Renewable energy consumption in each country every year. Unit: Mega Joule.

Non-renewable energy: Non-renewable energy consumption in each country each year. Unit: Mega Joule.

Output Variables:

GDP (desirable output): GDP in each country each year. Unit: billion dollars at current price.

The Second Stage: the Health Treatment Stage

Input Variables:

Healthy Expenditure: Total annual health expenditure in each country. Unit: billion dollars.

Output Variables:

Mortality rate of children (undesirable output): Mortality rate of children that is less than 5 years old in each country each year. Unit: percent.

Mortality rate of the aged (undesirable output): Mortality rate of the aged that is more than 65 years old in each country each year. Unit: percent.

Survival rate (desirable output): Survival rate is that of 65 years old in each country each year. Unit: percent. 
Tuberculosis rate (undesirable output): Excessive content of $\mathrm{CO}_{2}$ and PM2.5 in the air will reduce people's immunity to pulmonary tuberculosis, thus increasing the incidence of pulmonary tuberculosis. Tuberculosis rate is that in each country each year. Unit: \%oo.

Link Production Stage and the Health Treatment Stage Variables

$\mathrm{CO}_{2}: \mathrm{CO}_{2}$ emissions in each country each year. Unit: million ton.

PM2.5: The content of PM2.5 in the air in each country each year. Unit: Micrograms per cubic meter.

Carry Over Production Stage and the Health Treatment Stage Variable

Fixed assets: Capital stock of each country is calculated by fixed assets investment in each country by the end of each year. Unit: Billion dollars.

\subsection{Input and Output Variables Statistical Analysis}

Before the empirical study, this paper has carried out isotonicity test to justify the selection of variables. Table 3 shows a statistical table of the overall input and output variables of EU countries. As we show, they are labor by million persons, capital fixed assets by billion dollars, renewable energy by mega joule, non-renewable energy by mega joule, GDP by billion dollars, CO2 by million ton, PM2.5 by micrograms per cubic meter, health expenditure by billion dollars, tuberculosis rate per ten thousand, mortality rate of children by percent, mortality rate of adults by percent and survival rate of 65 years old by percent. The average values of PM2.5, CO2, non-renewable energy, tuberculosis rate, and mortality rate of children and adults and survival rate of 65 years old decreased obviously from 2010 to 2014. The average values of labor, capital, GDP, and health expenditure are not changed too much.

The minimum values of most variables are nearly 0 and they are not very clear in the picture. The minimum values of PM2.5, mortality rate of children and adults declined from 2010 to 2014. The minimum values of labor and survival rate of 65 years old were not change too much from 2010 to 2014 .

The maximum values of labor and survival rate of 65 years old were not changed too much from 2010 to 2014. The maximum and average values of CO2, non-renewable energy, tuberculosis rate, mortality rate of children and adults declined from 2010 to 2014. The maximum and average values of capital, GDP, renewable energy, and health expenditure increased from 2010 to 2014.

Table 4 shows a statistical table of the overall input and output variables of non-EU countries. The minimum values of most variables are nearly 0 .

The average values of labor, capital, renewable energy, non-renewable energy, and GDP were not change too much from 2010 to 2014. The average values of PM2.5, survival rate of 65 years old, tuberculosis rate, mortality rate of children and adults declined from 2010 to 2014 . The average values of health expenditure increased from 2010 to 2014.

The minimum values of PM2.5 decreased a little and that of mortality rate of children and adults were not change too much from 2010 to 2014. But the minimum value of survival rate of 65 years old increased significantly from 2010 to 2014.

The maximum values of tuberculosis rate, mortality rate of children and adults declined from 2010 to 2014. The maximum values of $\mathrm{CO}_{2}$, non-renewable energy, capital, GDP, renewable energy, and health expenditure increased from 2010 to 2014. The maximum values of labor and survival rate of 65 years old were not change from 2010 to 2014. 
Table 3. Statistics of input and output variables of EU countries.

\begin{tabular}{|c|c|c|c|c|c|c|c|c|c|c|c|c|c|}
\hline Item & Year & Labor & Capital & Re Energy & $\begin{array}{l}\text { Non-Re } \\
\text { Energy }\end{array}$ & GDP & $\mathrm{CO}_{2}$ & PM2.5 & Health $\operatorname{Exp}^{1}$ & Tub Rate ${ }^{2}$ & Mor.Ch ${ }^{3}$ & Mor.Ad $^{4}$ & Sur Rate ${ }^{5}$ \\
\hline \multirow{5}{*}{ Average } & 2010 & 7.87 & 121.74 & 213.37 & 1433.03 & 607.49 & 132.49 & 15.83 & 46.59 & 0.02 & 0.51 & 19.41 & 73.00 \\
\hline & 2011 & 7.85 & 132.24 & 207.78 & 1350.08 & 656.24 & 127.43 & 16.02 & 49.87 & 0.02 & 0.49 & 18.88 & 62.35 \\
\hline & 2012 & 7.83 & 121.82 & 226.00 & 1333.93 & 618.46 & 124.79 & 14.78 & 47.22 & 0.02 & 0.47 & 17.78 & 52.36 \\
\hline & 2013 & 7.82 & 124.15 & 238.67 & 1320.52 & 644.75 & 122.20 & 14.29 & 50.41 & 0.02 & 0.46 & 17.29 & 48.24 \\
\hline & 2014 & 7.91 & 129.14 & 241.26 & 1246.13 & 666.76 & 115.78 & 13.81 & 52.23 & 0.02 & 0.45 & 16.74 & 46.85 \\
\hline \multirow{5}{*}{ Max } & 2010 & 39.09 & 664.13 & 889.17 & 7748.99 & 3417.09 & 758.86 & 27.18 & 313.45 & 0.11 & 1.15 & 38.23 & 89.36 \\
\hline & 2011 & 39.27 & 761.54 & 935.66 & 7275.93 & 3757.70 & 732.50 & 26.37 & 335.06 & 0.10 & 1.13 & 36.90 & 90.14 \\
\hline & 2012 & 39.56 & 712.77 & 997.31 & 7303.14 & 3543.98 & 739.86 & 24.26 & 317.21 & 0.09 & 1.11 & 35.95 & 90.14 \\
\hline & 2013 & 40.00 & 739.22 & 1030.49 & 7493.64 & 3752.51 & 757.31 & 22.93 & 343.77 & 0.09 & 1.06 & 35.74 & 90.14 \\
\hline & 2014 & 40.34 & 779.52 & 1087.82 & 7043.06 & 3898.73 & 719.88 & 22.21 & 360.58 & 0.09 & 1.00 & 33.48 & 90.14 \\
\hline \multirow{5}{*}{ Min } & 2010 & 0.16 & 1.87 & 0.23 & 16.62 & 8.74 & 2.56 & 7.19 & 0.46 & 0.00 & 0.30 & 11.32 & 7.42 \\
\hline & 2011 & 0.17 & 1.71 & 0.33 & 15.97 & 9.50 & 2.54 & 7.28 & 0.52 & 0.00 & 0.29 & 11.20 & 7.42 \\
\hline & 2012 & 0.17 & 1.67 & 0.44 & 16.62 & 9.21 & 2.68 & 6.60 & 0.52 & 0.01 & 0.28 & 10.92 & 7.42 \\
\hline & 2013 & 0.18 & 1.77 & 0.45 & 17.16 & 10.15 & 2.34 & 6.28 & 0.61 & 0.01 & 0.26 & 10.58 & 7.42 \\
\hline & 2014 & 0.19 & 1.94 & 0.71 & 17.48 & 11.28 & 2.35 & 6.47 & 0.65 & 0.00 & 0.25 & 10.27 & 7.42 \\
\hline \multirow{5}{*}{ St. Dev ${ }^{6}$} & 2010 & 10.10 & 177.94 & 243.93 & 1951.48 & 905.40 & 177.88 & 4.84 & 76.20 & 0.02 & 0.21 & 7.50 & 21.96 \\
\hline & 2011 & 10.12 & 196.23 & 234.00 & 1820.57 & 981.83 & 170.35 & 4.87 & 81.36 & 0.02 & 0.20 & 7.25 & 29.92 \\
\hline & 2012 & 10.15 & 182.99 & 258.56 & 1831.23 & 933.66 & 171.07 & 4.52 & 77.48 & 0.02 & 0.19 & 6.87 & 32.89 \\
\hline & 2013 & 10.20 & 187.71 & 271.71 & 1843.31 & 975.36 & 171.28 & 4.29 & 83.90 & 0.02 & 0.18 & 6.71 & 32.06 \\
\hline & 2014 & 10.31 & 196.39 & 273.61 & 1722.50 & 1018.17 & 160.71 & 4.11 & 88.22 & 0.02 & 0.17 & 6.57 & 31.59 \\
\hline
\end{tabular}

${ }^{1}$ Healthy expenditure; ${ }^{2}$ Tuberculosis rate; ${ }^{3}$ Mortality rate of children; ${ }^{4}$ Mortality rate of the aged; ${ }^{5}$ Survival rate; ${ }^{6}$ Standard deviation. 
Table 4. Statistics of input and output variables of non-EU countries.

\begin{tabular}{|c|c|c|c|c|c|c|c|c|c|c|c|c|c|}
\hline Item & Year & Labor & Capital & Re Energy & Non-Re Energy & GDP & $\mathrm{CO}_{2}$ & PM2.5 & Health $\operatorname{Exp}^{1}$ & Tub Rate $^{2}$ & Mor.Ch $^{3}$ & Mor.Ad $^{4}$ & Sur Rate ${ }^{5}$ \\
\hline \multirow{5}{*}{ Average } & 2010 & 42.21 & 209.14 & 726.94 & 3876.00 & 848.65 & 489.35 & 32.36 & 45.94 & 0.13 & 2.43 & 29.79 & 72.14 \\
\hline & 2011 & 42.61 & 240.58 & 739.55 & 4001.06 & 953.12 & 511.98 & 32.38 & 51.91 & 0.13 & 2.32 & 29.06 & 71.26 \\
\hline & 2012 & 42.99 & 259.19 & 759.33 & 4042.52 & 997.89 & 523.19 & 31.50 & 54.57 & 0.12 & 2.22 & 28.15 & 67.90 \\
\hline & 2013 & 43.46 & 270.43 & 778.22 & 4130.98 & 1021.12 & 529.45 & 30.84 & 55.19 & 0.12 & 2.12 & 27.66 & 63.76 \\
\hline & 2014 & 43.92 & 280.22 & 794.10 & 4201.18 & 1044.83 & 537.27 & 29.67 & 74.50 & 0.12 & 2.04 & 27.17 & 57.82 \\
\hline \multirow{4}{*}{ Max } & 2010 & 744.86 & 2756.06 & 7871.45 & $53,328.08$ & $14,992.05$ & 8776.04 & 100.78 & 1194.31 & 0.95 & 12.96 & 89.88 & 89.36 \\
\hline & 2011 & 747.79 & 3399.69 & 7655.96 & $57,803.12$ & $15,542.58$ & 9733.54 & 100.77 & 1233.85 & 0.92 & 12.47 & 84.98 & 90.14 \\
\hline & 2013 & 750.81 & 4372.71 & 8275.65 & $61,630.89$ & $16,784.85$ & $10,258.01$ & 95.31 & 1339.61 & 0.86 & 11.56 & 76.82 & 90.14 \\
\hline & 2014 & 751.92 & 4721.38 & 8744.47 & $62,791.84$ & $17,521.75$ & $10,291.93$ & 98.12 & 2353.21 & 0.82 & 11.16 & 73.55 & 90.14 \\
\hline \multirow{5}{*}{ Min } & 2010 & 0.17 & 1.33 & 0.01 & 25.87 & 4.79 & 1.96 & 7.15 & 0.14 & 0.00 & 0.27 & 10.69 & 36.84 \\
\hline & 2011 & 0.17 & 1.47 & 0.01 & 24.83 & 6.20 & 1.88 & 7.37 & 0.16 & 0.00 & 0.26 & 10.11 & 7.42 \\
\hline & 2012 & 0.18 & 2.07 & 0.01 & 24.64 & 6.61 & 1.80 & 6.84 & 0.17 & 0.00 & 0.25 & 10.12 & 7.42 \\
\hline & 2013 & 0.18 & 2.17 & 0.01 & 26.81 & 7.34 & 1.90 & 6.71 & 0.17 & 0.00 & 0.24 & 10.57 & 7.42 \\
\hline & 2014 & 0.19 & 2.43 & 0.01 & 27.00 & 7.47 & 1.98 & 6.18 & 0.19 & 0.00 & 0.23 & 10.00 & 7.42 \\
\hline \multirow{4}{*}{ St. Dev ${ }^{6}$} & 2011 & 116.97 & 621.21 & 1662.53 & $10,600.66$ & 2436.40 & 1500.75 & 21.75 & 182.13 & 0.18 & 2.52 & 17.00 & 22.99 \\
\hline & 2012 & 117.19 & 688.57 & 1713.30 & $10,690.19$ & 2562.51 & 1529.36 & 21.27 & 189.64 & 0.17 & 2.42 & 16.29 & 27.08 \\
\hline & 2013 & 117.88 & 745.37 & 1753.42 & $11,000.86$ & 2653.38 & 1557.78 & 20.98 & 192.92 & 0.17 & 2.32 & 15.76 & 29.19 \\
\hline & 2014 & 118.62 & 798.57 & 1805.75 & $11,223.53$ & 2780.17 & 1569.61 & 20.52 & 324.34 & 0.16 & 2.24 & 15.33 & 30.93 \\
\hline
\end{tabular}

${ }^{1}$ Healthy expenditure; ${ }^{2}$ Tuberculosis rate; ${ }^{3}$ Mortality rate of children; ${ }^{4}$ Mortality rate of the aged; ${ }^{5}$ Survival rate; ${ }^{6}$ Standard deviation. 


\subsection{Total Annual Efficiency Scores}

The overall efficiencies in each EU country from 2010 to 2014 are showed in the Table 5. An overall efficiency of 1 in all four years was achieved by Malta. Cyprus and Sweden's efficiencies were 1 in 2012 and 2013. Luxembourg's efficiency was 1 in 2010, but that declined below 0.7 from 2011.Therefore, there are many other EU countries that need to improvement the efficiency scores.

Bulgaria, Hungary, Poland, and Romania's efficiencies of each year were below 0.2 from 2010 to 2014 and Czech's overall efficiency was also below 0.2, and the efficiencies of Austria, Croatia, Latvia, Lithuania, and Slovak were between 0.2 to 0.3 . These countries are all local in the east Europe. Except Malta, Cyprus, and Sweden; there are Finland, Greece, Italy, Luxembourg, Netherlands, and Sweden where efficiencies were over 0.5 . Therefore, there were 9 countries where efficiencies were over 0.5 and 10 countries where efficiencies were below 0.3 in EU countries of 28 .

In the non-EU countries of 53, there are 6 countries where overall efficiencies were 1 in all four years, as showed in the Table 6. These countries are Brunei, Japan, Iceland, Saudi Arabia, Singapore, and United States. There are four years that United Arab Emirates and Korea's efficiencies were 1 in five years. Australia, Mongolia, and Norway's efficiencies were 1 in 2010, but those declined below 0.6 in 2014. Switzerland's efficiency was 1 in 2012 to 2013, but those overall efficiencies were below 0.6 in other years.

Australia, Canada, Korea, New Zealand, Switzerland, United Arab Emirates total efficiencies were above 0.6 and those countries are developing countries. Albania, Cambodia, Cuba, Nepal, Norway, Iraq, Israel's total efficiencies were between 0.5 to 0.6 . Therefore, there were 19 countries where efficiencies were over 0.5 in non-EU countries of 53.

India, Vietnam, South Africa, and Ukraine's efficiencies were below 0.1 from 2010 to 2014. Those countries' efficiencies were the lowest. Brazil, Bangladesh, Belarus, Chile, China, Colombia, Iran, Morocco, Kazakhstan, Kenya, Malaysia, Mexico, Peru, Philippines, Thailand, Tunisia, and Turkey's efficiencies were below 0.2 in most or all year from 2010 to 2014. Algeria, Argentina, Cameroon, Costa Rica, Pakistan, and Sri Lanka's total efficiencies were between 0.2 to 0.3 . Therefore, there were 27 countries where efficiencies were below 0.3 in non-EU countries of 53 .

The overall efficiencies in non-EU countries were worse than those in EU countries. There are half countries where overall efficiencies were below 0.3 but that is one-third of the EU countries. We can also prove this from the average value of overall efficiencies in EU and non-EU countries. The average values of overall efficiencies are higher in EU countries than that in non-EU countries each year from 2010 to 2014. This basically proves the hypothesis:"H1: The average overall efficiency of EU countries is higher than that of non-EU countries." 
Table 5. Overall efficiency by EU countries from 2010 to 2014.

\begin{tabular}{|c|c|c|c|c|c|c|c|c|c|c|c|c|c|c|c|}
\hline No. & DMU 1 & 2010 & 2011 & 2012 & 2013 & 2014 & $\begin{array}{l}\text { Annual } \\
\text { Average }\end{array}$ & No. & DMU & 2010 & 2011 & 2012 & 2013 & 2014 & $\begin{array}{l}\text { Annual } \\
\text { Average }\end{array}$ \\
\hline 1 & Austria & 0.3254 & 0.2855 & 0.2925 & 0.3035 & 0.2936 & 0.2687 & 16 & Latvia & 0.2279 & 0.2592 & 0.2615 & 0.2761 & 0.2983 & 0.2635 \\
\hline 2 & Belgium & 0.4094 & 0.4124 & 0.3752 & 0.3875 & 0.3742 & 0.3498 & 17 & Lithuania & 0.2192 & 0.3063 & 0.2422 & 0.2630 & 0.2331 & 0.2372 \\
\hline 3 & Bulgaria & 0.1513 & 0.1713 & 0.1705 & 0.1734 & 0.1572 & 0.1620 & 18 & Luxembour & rg 1 & 0.6521 & 0.6343 & 0.6278 & 0.6363 & 0.6866 \\
\hline 4 & Croatia & 0.2178 & 0.2105 & 0.2185 & 0.2356 & 0.2078 & 0.2067 & 19 & Malta & 1 & 1 & 1 & 1 & 1 & 1 \\
\hline 5 & Cyprus & 0.8020 & 0.7983 & 1 & 1 & 0.9206 & 0.9023 & 20 & Netherland & 18.5992 & 0.5262 & 0.5314 & 0.5294 & 0.5310 & 0.5184 \\
\hline 6 & Czech & 0.2099 & 0.2016 & 0.1932 & 0.1845 & 0.1668 & 0.1801 & 21 & Poland & 0.1718 & 0.1663 & 0.1560 & 0.1646 & 0.1607 & 0.1473 \\
\hline 7 & Denmark & 0.5344 & 0.5225 & 0.5224 & 0.5245 & 0.5236 & 0.4772 & 22 & Portugal & 0.3086 & 0.2842 & 0.3564 & 0.5373 & 0.2805 & 0.3134 \\
\hline 8 & Estonia & 0.3581 & 0.3845 & 0.3863 & 0.3863 & 0.3935 & 0.3923 & 23 & Romania & 0.1325 & 0.1149 & 0.1175 & 0.1279 & 0.1234 & 0.1103 \\
\hline 9 & Finland & 0.8102 & 0.6320 & 0.6518 & 0.8002 & 0.3830 & 0.6527 & 24 & Slovak & 0.2098 & 0.2262 & 0.2211 & 0.2255 & 0.2178 & 0.2051 \\
\hline 10 & France & 0.5133 & 0.5118 & 0.5155 & 0.5151 & 0.5147 & 0.4693 & 25 & Slovenia & 0.3133 & 0.3118 & 0.3111 & 0.3158 & 0.3124 & 0.3074 \\
\hline 11 & Germany & 0.5810 & 0.5769 & 0.4709 & 0.6121 & 0.5965 & 0.5579 & 26 & Spain & 0.3755 & 0.3601 & 0.3310 & 0.3547 & 0.3343 & 0.3190 \\
\hline 12 & Greece & 0.8982 & 0.5561 & 0.5949 & 0.5891 & 0.5941 & 0.6248 & 27 & Sweden & 0.8569 & 0.8487 & 1 & 1 & 0.4086 & 0.8137 \\
\hline 13 & Hungary & 0.1782 & 0.1721 & 0.1809 & 0.1800 & 0.1710 & 0.1604 & 28 & $\begin{array}{l}\text { United } \\
\text { Kingdom }\end{array}$ & 0.5196 & 0.5191 & 0.5228 & 0.5225 & 0.5213 & 0.4671 \\
\hline $\begin{array}{l}14 \\
15\end{array}$ & $\begin{array}{l}\text { Ireland } \\
\text { Italy }\end{array}$ & $\begin{array}{l}0.5346 \\
0.9077\end{array}$ & $\begin{array}{l}0.5345 \\
0.5308\end{array}$ & $\begin{array}{l}0.5371 \\
0.4815\end{array}$ & $\begin{array}{l}0.5408 \\
0.6925\end{array}$ & $\begin{array}{l}0.5442 \\
0.8548\end{array}$ & $\begin{array}{l}0.4868 \\
0.6928\end{array}$ & \multicolumn{2}{|c|}{ Average in EU } & 0.4774 & 0.4313 & 0.4384 & 0.4668 & 0.4198 & 0.4276 \\
\hline
\end{tabular}


Table 6. Overall efficiency by non-EU countries from 2010 to 2014.

\begin{tabular}{|c|c|c|c|c|c|c|c|c|c|c|c|c|c|c|c|}
\hline No. & DMU & 2010 & 2011 & 2012 & 2013 & 2014 & $\begin{array}{l}\text { Annual } \\
\text { Average }\end{array}$ & No. & DMU & 2010 & 2011 & 2012 & 2013 & 2014 & $\begin{array}{l}\text { Annual } \\
\text { Average }\end{array}$ \\
\hline 1 & Albania & 0.6137 & 0.6052 & 0.6220 & 0.6253 & 0.6283 & 0.5342 & 28 & Kyrgyz & 0.6202 & 0.4412 & 0.3579 & 0.3423 & 0.3520 & 0.3456 \\
\hline 2 & Algeria & 0.1942 & 0.2243 & 0.2142 & 0.2387 & 0.2922 & 0.2050 & 29 & Malaysia & 0.1846 & 0.1824 & 0.1679 & 0.1672 & 0.1568 & 0.1623 \\
\hline 3 & Argentina & 0.1760 & 0.5447 & 0.2203 & 0.1942 & 0.1598 & 0.2194 & 30 & Mexico & 0.1981 & 0.1932 & 0.1863 & 0.2026 & 0.1909 & 0.1721 \\
\hline 4 & Australia & 1 & 0.7938 & 0.5463 & 0.5482 & 0.5544 & 0.6637 & 31 & Mongolia & 1 & 0.4363 & 0.3377 & 0.3674 & 0.3815 & 0.4446 \\
\hline 5 & Bangladesh & 0.2024 & 0.1844 & 0.1932 & 0.1966 & 0.1923 & 0.1977 & 32 & Morocco & 0.1550 & 0.1421 & 0.1268 & 0.1335 & 0.1366 & 0.1378 \\
\hline 6 & Belarus & 0.1094 & 0.1248 & 0.1123 & 0.1200 & 0.1211 & 0.1190 & 33 & Nepal & 0.6480 & 0.6417 & 0.6342 & 0.6317 & 0.6218 & 0.5656 \\
\hline 7 & Botswana & 0.1988 & 0.1870 & 0.2156 & 0.2319 & 0.2337 & 0.2144 & 34 & New Zealand & 0.7662 & 0.7806 & 0.7998 & 0.5886 & 0.8050 & 0.7364 \\
\hline 8 & Brazil & 0.2380 & 0.2441 & 0.2223 & 0.2415 & 0.2153 & 0.1847 & 35 & Nigeria & 0.6752 & 0.6660 & 0.6282 & 0.6284 & 0.6274 & 0.4691 \\
\hline 9 & Brunei & 1 & 1 & 1 & 1 & 1 & 1 & 36 & Norway & 1 & 0.5210 & 0.5219 & 0.5258 & 0.5260 & 0.5798 \\
\hline 10 & Cambodia & 0.5109 & 0.6223 & 0.4937 & 0.4455 & 0.4700 & 0.5100 & 37 & Pakistan & 0.2217 & 0.2831 & 0.2861 & 0.2178 & 0.1868 & 0.2508 \\
\hline 11 & Cameroon & 0.1973 & 0.1608 & 0.2049 & 0.2451 & 0.2718 & 0.2112 & 38 & Peru & 0.1505 & 0.1283 & 0.1731 & 0.1536 & 0.1303 & 0.1317 \\
\hline 12 & Canada & 0.8287 & 0.8233 & 0.4579 & 0.8264 & 0.8222 & 0.7422 & 39 & Philippines & 0.1486 & 0.1554 & 0.1871 & 0.1787 & 0.1543 & 0.1505 \\
\hline 13 & Chile & 0.1732 & 0.1526 & 0.1907 & 0.1590 & 0.1455 & 0.1485 & 40 & Russian & 0.1448 & 0.1742 & 0.1944 & 0.2136 & 0.1927 & 0.1457 \\
\hline 14 & China & 0.1098 & 0.1203 & 0.1333 & 0.1478 & 0.1398 & 0.1245 & 41 & Saudi Arabia & 1 & 1 & 1 & 1 & 1 & 1 \\
\hline 15 & Colombia & 0.1841 & 0.1596 & 0.2021 & 0.1941 & 0.1665 & 0.1519 & 42 & Serbia & 0.1481 & 0.1685 & 0.1585 & 0.1681 & 0.1565 & 0.1562 \\
\hline 16 & Costa Rica & 0.2579 & 0.2596 & 0.3080 & 0.2787 & 0.2527 & 0.2580 & 43 & Singapore & 1 & 1 & 1 & 1 & 1 & 1 \\
\hline 17 & Cuba & 0.5887 & 0.5930 & 0.6171 & 0.5786 & 0.5459 & 0.5441 & 44 & South Africa & 0.1241 & 0.1195 & 0.1225 & 0.1034 & 0.0909 & 0.0715 \\
\hline 18 & Georgia & 0.4444 & 0.7162 & 0.4121 & 0.3884 & 0.3323 & 0.4525 & 45 & Sri Lanka & 0.2168 & 0.2073 & 0.2060 & 0.1949 & 0.1974 & 0.2038 \\
\hline 19 & Iceland & 1 & 1 & 1 & 1 & 1 & 1 & 46 & Switzerland & 0.5177 & 0.5149 & 0.5202 & 1 & 1 & 0.6872 \\
\hline 20 & India & 0.0690 & 0.0595 & 0.0604 & 0.0609 & 0.0555 & 0.0582 & 47 & Thailand & 0.0843 & 0.0722 & 0.0789 & 0.0818 & 0.0700 & 0.0702 \\
\hline 21 & Iran & 0.1969 & 0.2160 & 0.2138 & 0.1819 & 0.0908 & 0.1686 & 48 & Tunisia & 0.1821 & 0.1756 & 0.1586 & 0.1569 & 0.1581 & 0.1655 \\
\hline 22 & Iraq & 0.2903 & 0.7368 & 1.0000 & 1.0000 & 0.2420 & 0.5941 & 49 & Turkey & 0.2091 & 0.1742 & 0.1780 & 0.1988 & 0.1839 & 0.1602 \\
\hline 23 & Israel & 0.8999 & 0.4283 & 0.4939 & 0.5991 & 0.5964 & 0.5802 & 50 & Ukraine & 0.0775 & 0.1029 & 0.1174 & 0.0956 & 0.0805 & 0.0895 \\
\hline 24 & Japan & 1 & 1 & 1 & 1 & 1 & 1 & 51 & $\begin{array}{c}\text { United Arab } \\
\text { Emirates }\end{array}$ & 0.8872 & 1 & 1 & 1 & 1 & 0.9774 \\
\hline 25 & Kazakhstan & 0.1328 & 0.1667 & 0.1883 & 0.2371 & 0.1949 & 0.1647 & 52 & United States & 1 & 1 & 1 & 1 & 1 & 1 \\
\hline 26 & Kenya & 0.1442 & 0.1376 & 0.1904 & 0.1851 & 0.1720 & 0.1600 & 53 & Vietnam & 0.0605 & 0.0558 & 0.0631 & 0.0586 & 0.0594 & 0.0584 \\
\hline 27 & Korea, Rep. & 1 & 1 & 1 & 1 & 0.4335 & 0.8662 & Ave & e in non-EU & 0.4374 & 0.4264 & 0.4098 & 0.4214 & 0.3922 & 0.3963 \\
\hline
\end{tabular}




\subsection{Total Average Efficiency Scores Analysis in Each Stage}

From the view of each stage, the overall efficiencies of EU and non-EU countries have different performance. Because there are too many countries in EU and non-EU, we use the average values of the overall efficiencies of EU and non-EU countries to compare the difference between EU and non-EU countries. We can see the results in the Table 7, the average overall efficiencies of EU countries are higher than those of non-EU countries each year from 2010 to 2014 in the first stage (production stage). The average overall efficiencies of non-EU countries are below 0.47 in the first stage, but those of EU countries are above 0.61 for each year. Therefore, the energy efficiencies in non-EU countries is lower than EU countries and there are much more spaces to improve the energy efficiencies in non-EU countries. This basically proves the hypothesis:" $\mathrm{H} 2$ : The overall energy efficiency of EU countries is higher than that of non-EU countries."

Table 7. Average overall efficiency in EU and non-EU countries from 2010 to 2014 in each stage.

\begin{tabular}{ccccccc}
\hline Countries & 2010-I & 2011-I & 2012-I & 2013-I & 2014-I & Stage I \\
\hline EU Countries (28) & 0.6165 & 0.6159 & 0.6349 & 0.6659 & 0.6159 & 0.6298 \\
Non-EU Countries (53) & 0.4532 & 0.4679 & 0.4633 & 0.4673 & 0.4362 & 0.4576 \\
\hline Countries & $2010-\mathrm{II}$ & $2011-\mathrm{II}$ & $2012-\mathrm{II}$ & $2013-\mathrm{II}$ & 2014-II & Stage II \\
\hline EU Countries (28) & 0.3382 & 0.2466 & 0.242 & 0.2676 & 0.2237 & 0.2636 \\
Non-EU Countries (53) & 0.4216 & 0.3848 & 0.3562 & 0.3754 & 0.3482 & 0.3772 \\
\hline
\end{tabular}

But the average overall efficiencies of EU countries are lower than those of non-EU countries each year from 2010 to 2014 in the second stage (health treatment stage). The average overall efficiencies of EU countries are below 0.27 except 0.3382 in 2010 from 2010 to 2014 in the second stage, but those of EU countries are above 0.34 for each year from 2010 to 2014 . Therefore, the healthy efficiencies in EU countries is lower than non-EU countries and there is much more space to improve the healthy efficiencies in EU countries.

Meanwhile, the average overall efficiencies of EU and non-EU countries each year in the second stage are all lower than those in the first stage, especially for EU countries. Thus, there are much more spaces to improve for the healthy efficiencies than for the energy efficiencies in EU countries and non-EU countries. This proves that the hypothesis "H3: The overall health efficiency of EU countries is higher than that of non-EU countries" is not true.

\subsection{The Technical Efficiency of the Group Frontier for EU and Non-EU countries}

We can learn the technical efficiency of the group frontier for EU and non-EU countries from the technology gap ratio (TGR) of EU and non-EU countries from 2010 to 2014, as showed in Table 8. In the non-EU countries of 53, there are 7 countries where TGRs were 1 in all four years. These countries are Brunei, Japan, Iceland, Nigeria, Saudi Arabia, Singapore, and United States. United Arab Emirates and Korea's efficiencies were 1 in five years. In the EU of 28 countries, there are only 1 country where TGR was 1 in all four years and it is Malta.

Table 8 showed that the average overall TGRs were higher obviously each year in non-EU countries than those countries in EU. Only the average overall TGR was over 0.7 in 2010 for EU countries, another TGRs were below 0.37 from 2011 to 2014. But TGRs were above 0.85 for non-EU countries each year from 2010 to 2014.

The explanation for this phenomenon is mainly due to the TGRs of EU countries in the second stage was lower significantly than non-EU countries from 2011 to 2014. The TGRs of EU countries in the second stage were all below 0.48 , but those of non-EU countries were above 0.84 each year from 2010 to 2014. However, in the first phase, the TGRs of EU countries were higher than those of non-EU countries. Thus, EU countries have a bigger gap between group frontier (GF) and meta-frontier (MF) 
in the healthy treatment stage, and the TGRs of non-EU countries were very close and high in the production stage and the healthy treatment stages from 2011 to 2014.

Table 8. Average overall TGRs of EU and non-EU countries from 2010 to 2014.

\begin{tabular}{ccccccc}
\hline Countries & $\mathbf{2 0 1 0}$ & $\mathbf{2 0 1 1}$ & $\mathbf{2 0 1 2}$ & $\mathbf{2 0 1 3}$ & $\mathbf{2 0 1 4}$ & Total \\
\hline EU Countries (28) & 0.7234 & 0.3485 & 0.345 & 0.3641 & 0.3506 & 0.6592 \\
Non-EU Countries (53) & 0.8739 & 0.8625 & 0.8574 & 0.8554 & 0.8743 & 0.8524 \\
\hline Countries & $2010(\mathrm{I})$ & $2011(\mathrm{I})$ & $2012(\mathrm{I})$ & $2013(\mathrm{I})$ & $2014(\mathrm{I})$ & stage(I) \\
\hline EU Countries (28) & 0.895 & 0.886 & 0.878 & 0.919 & 0.889 & 0.889 \\
Non-EU Countries (53) & 0.874 & 0.871 & 0.863 & 0.858 & 0.883 & 0.861 \\
\hline Countries & $2010(\mathrm{II})$ & $2011(\mathrm{II})$ & $2012(\mathrm{II})$ & $2013(\mathrm{II})$ & $2014(\mathrm{II})$ & stage (II) \\
\hline EU Countries (28) & 0.478 & 0.386 & 0.387 & 0.408 & 0.382 & 0.406 \\
Non-EU Countries (53) & 0.875 & 0.848 & 0.860 & 0.849 & 0.855 & 0.853 \\
\hline
\end{tabular}

\subsection{The Efficiency of the Input and Output Variables}

We can learn the energy efficiencies for the inputs and outputs from the production stage in EU countries and non-EU countries. As the Table 9 showed, the GDP efficiencies were all above 0.92 each year for EU countries and non-EU countries. The non-renewable energy, renewable energy, labor, $\mathrm{PM} 2.5$, and $\mathrm{CO}_{2}$ efficiencies of EU countries were all higher than ones of non-EU countries from 2010 to 2014. The gap of renewable energy, PM2.5 and $\mathrm{CO}_{2}$ efficiencies between EU countries and non-EU countries were more significant. There are much more space for the non-EU countries to improve the energy efficiencies of inputs and outputs. This basically proves the hypothesis: "H4: In each of the energy efficiencies, EU countries are higher than non-EU countries."

Meanwhile, the renewable energy efficiencies were obviously higher than the non-renewable energy efficiencies and PM2.5 efficiencies were obviously higher than the $\mathrm{CO}_{2}$ efficiencies for EU countries and non-EU countries.

Table 9. Comparison of energy efficiencies during 2010 to 2014.

\begin{tabular}{cccccccc}
\hline Year & Countries & $\begin{array}{c}\text { Non-Renewable } \\
\text { Energy }\end{array}$ & $\begin{array}{c}\text { Renewable } \\
\text { Energy }\end{array}$ & Labor & GDP & CO $_{2}$ & PM2.5 $^{2}$ \\
\hline \multirow{2}{*}{2010} & Non-EU & 0.3992 & 0.5866 & 0.4318 & 0.9562 & 0.5902 & 0.7609 \\
& EU & 0.4336 & 0.7302 & 0.6860 & 0.9998 & 0.7464 & 0.8920 \\
2011 & Non-EU & 0.4139 & 0.5760 & 0.4590 & 0.9500 & 0.5956 & 0.7504 \\
& EU & 0.4779 & 0.6984 & 0.6754 & 0.9979 & 0.6910 & 0.8217 \\
2012 & Non-EU & 0.3866 & 0.5953 & 0.4430 & 0.9610 & 0.5856 & 0.7593 \\
& EU & 0.5337 & 0.6786 & 0.6931 & 0.9987 & 0.6801 & 0.8837 \\
2013 & Non-EU & 0.4286 & 0.5827 & 0.4398 & 0.9519 & 0.5847 & 0.7865 \\
& EU & 0.5772 & 0.7138 & 0.7069 & 1.0000 & 0.7167 & 0.9165 \\
2014 & Non-EU & 0.4048 & 0.5668 & 0.4296 & 0.9276 & 0.5532 & 0.7272 \\
& EU & 0.5149 & 0.6703 & 0.6709 & 0.9929 & 0.6629 & 0.9318 \\
\hline \multirow{2}{*}{ Annual } & Non-EU & 0.4066 & 0.5815 & 0.4406 & 0.9493 & 0.5819 & 0.7568 \\
average & EU & 0.5075 & 0.6982 & 0.6864 & 0.9979 & 0.6994 & 0.8891 \\
\hline
\end{tabular}

We can learn the health efficiencies for the inputs and outputs from the health treatment stage in EU countries and non-EU countries. From the Table 10, we can see the survival rate efficiencies were all above 0.91 each year for EU countries and non-EU countries and there were 3 years that their values were 1 in all four years in EU countries. The tuberculosis rate efficiencies and mortality rate of children efficiencies of EU countries were all higher than one for non-EU countries from 2010 to 2014. The health expenditure efficiencies and the mortality rate of the adult efficiencies of EU countries were all lower than ones for non-EU countries from 2010 to 2014, except the mortality rate of the adult 
efficiencies in the 2014. There is much more space for the non-EU countries to improve the tuberculosis rate efficiencies and mortality rate of children efficiencies, and there are much more space for the EU countries to improve the health expenditure efficiencies and the mortality rate of the adult efficiencies. Meanwhile, the mortality rate of children efficiencies was higher than the mortality rate of the adult efficiencies for EU countries and non-EU countries. This proves the hypothesis: "H5: In each of the health efficiencies, EU countries are higher than non-EU countries" is not true.

Table 10. Comparison of health efficiencies during 2010 to 2014.

\begin{tabular}{ccccccc}
\hline Year & Countries & $\begin{array}{c}\text { Health } \\
\text { Expenditure }\end{array}$ & $\begin{array}{c}\text { Tuberculosis } \\
\text { Rate }\end{array}$ & $\begin{array}{c}\text { Mortality } \\
\text { Rate of } \\
\text { Children }\end{array}$ & $\begin{array}{c}\text { Mortality } \\
\text { Rate of the } \\
\text { Adult }\end{array}$ & $\begin{array}{c}\text { Survival } \\
\text { Rate of 65 } \\
\text { Years Old }\end{array}$ \\
\hline \multirow{2}{*}{2010} & Non-EU & 0.4688 & 0.5940 & 0.7322 & 0.7036 & 0.9307 \\
& EU & 0.3565 & 0.7421 & 0.8932 & 0.6784 & 1.0000 \\
2011 & Non-EU & 0.4358 & 0.6353 & 0.7201 & 0.7139 & 0.9132 \\
& EU & 0.2703 & 0.7357 & 0.8550 & 0.6602 & 1.0000 \\
2012 & Non-EU & 0.4150 & 0.5503 & 0.6861 & 0.6881 & 0.9190 \\
2013 & EU & 0.2709 & 0.6246 & 0.8397 & 0.6584 & 1.0000 \\
& Non-EU & 0.4267 & 0.5633 & 0.7188 & 0.7045 & 0.9281 \\
2014 & EU & 0.2954 & 0.6148 & 0.8101 & 0.6921 & 0.9966 \\
& Non-EU & 0.4025 & 0.5237 & 0.6662 & 0.7013 & 0.9176 \\
Annual & EU & 0.2506 & 0.5613 & 0.7913 & 0.7276 & 1.0000 \\
Average & Non-EU & 0.4298 & 0.5733 & 0.7047 & 0.7023 & 0.9217 \\
\hline
\end{tabular}

Because the health expenditure efficiencies are very low and there is different performance between the children and the adult mortality rate, we analyzed in detail the specific situation of health efficiencies of each EU and non-EU country. The results are showed in the Tables 9 and 10.

In the EU countries (see Table 11), there are 2 countries where health expenditure efficiencies were 1 in all five years and they are Cyprus and Malta. There are 13 countries where health expenditure efficiencies were below 0.1 in the EU countries. Most of them are high welfare countries, for example, Belgium, Denmark, France, UK, Iceland, Netherlands, Spain, and Portugal.

There are 7 countries where children's mortality rate efficiencies were 1 in all five years and they are Cyprus, Estonia, Finland, Lithuania, Latvia, Slovenia, and Malta. The children's mortality rate efficiency in Slovak was at the least and it was 0.5693. Another countries' children's mortality rate efficiencies were above 0.62 in EU.

Table 11. Comparison of the annual health efficiencies of EU countries from 2010 to 2014.

\begin{tabular}{|c|c|c|c|c|c|c|c|c|c|}
\hline No. & Country & $\begin{array}{c}\text { Health } \\
\text { Expenditure }\end{array}$ & $\begin{array}{c}\text { Children's } \\
\text { Mortality } \\
\text { Rate }\end{array}$ & $\begin{array}{l}\text { Adult's } \\
\text { Mortality } \\
\text { Rate }\end{array}$ & No. & Country & $\begin{array}{l}\text { Health } \\
\text { Expenditure }\end{array}$ & $\begin{array}{c}\text { Children's } \\
\text { Mortality } \\
\text { Rate }\end{array}$ & $\begin{array}{l}\text { Adult's } \\
\text { Mortality } \\
\text { Rate }\end{array}$ \\
\hline 2 & Belgium & 0.0509 & 0.6881 & 0.6753 & 16 & Ireland & 0.0959 & 0.6532 & 0.7720 \\
\hline 3 & Bulgaria & 0.1812 & 0.7185 & 0.8879 & 17 & Italy & 0.5189 & 0.9906 & 1 \\
\hline 4 & Cyprus & 1 & 1 & 1 & 18 & Lithuania & 0.2057 & 1 & 0.2700 \\
\hline 7 & Denmark & 0.0621 & 0.6801 & 0.6829 & 21 & Malta & 1 & 1 & 1 \\
\hline 8 & Spain & 0.0594 & 0.7769 & 0.8474 & 22 & Netherlands & 0.0941 & 0.8085 & 0.8911 \\
\hline 9 & Estonia & 0.6073 & 1 & 0.3787 & 23 & Poland & 0.0603 & 0.7638 & 0.4151 \\
\hline 10 & Finland & 0.8337 & 1 & 0.7984 & 24 & Portugal & 0.0972 & 0.7801 & 0.6238 \\
\hline 11 & France & 0.034 & 0.7863 & 0.6556 & 25 & Romania & 0.0504 & 0.8139 & 0.4553 \\
\hline
\end{tabular}


There are 3 countries where adult's mortality rate efficiencies were 1 in all five years and they are Cyprus, Italy, and Malta. There are 6 countries where adult's mortality rate efficiencies were above 0.8 in all five years and they are Bulgaria, Germany, Spain, Luxembourg, Netherlands, and Sweden. The adult's mortality rate efficiencies in Estonia, Hungary, and Lithuania were lower than the ones of other countries and they were $0.3787,0.3218,0.2700$ respectively.

In the non-EU countries (see Table 12), there are 9 countries where health expenditure efficiencies were 1 in all five years and they are Albania, United Arab, Brunei, Iceland, Japan, Nepal, Saudi Arabia, Singapore, and USA. There are 11 countries where health expenditure efficiencies were below 0.1 in the non-EU countries. They are Argentina, Chile, Colombia, India, Mexico, Peru, Thailand, Turkey, Ukraine, Vietnam, and South Africa.

There are 12 countries where the mortality rate of children efficiencies was 1 in all five years and they are Albania, United Arab, Belarus, Brunei, Iceland, Japan, Cambodia, Korea, Nepal, Saudi Arabia, Singapore, and USA. There are still other 8 countries where children's mortality rate efficiencies were above 0.8 . But there are 15 countries where children's mortality rate efficiencies were below 0.56 in all five years and the least value is 0.2742 in Brazil. But children's mortality rate efficiencies were all above 0.56 in EU countries each year.

There are 11 countries where adult's mortality rate efficiencies were 1 in all five years and they are Albania, United Arab, Brunei, Canada, China, Iceland, Japan, Nepal, Saudi Arabia, Singapore, and USA. There are still other 10 countries where adult's mortality rate efficiencies were above 0.8 in all five years. There are 5 countries where adult's mortality rate efficiencies were below 0.4 in all five years and they are Belarus, Botswana, Colombia, Kazakhstan, and Philippines in non-EU countries of 53 and they were $0.2221,0.3831,0.3381,0.2346,0.3576$ respectively. Relatively speaking, there are 3 countries where adult's mortality rate efficiencies were below 0.4 in EU countries of 28 .

Table 12. Comparison of the annual health efficiencies of non-EU countries from 2010 to 2014.

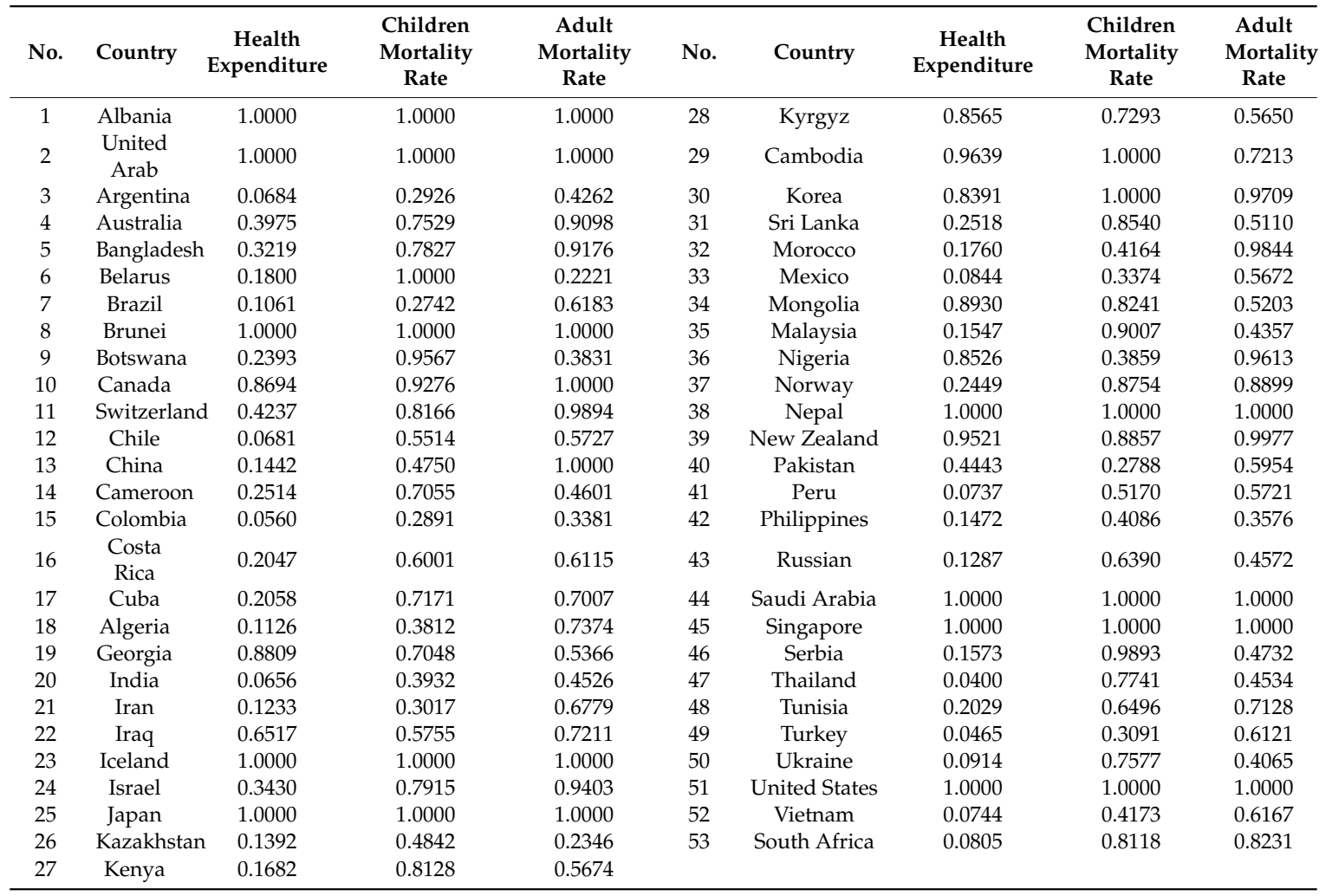




\section{Conclusions}

This study focuses on the energy efficiencies and health efficiencies in $28 \mathrm{EU}$ countries and 53 non-EU countries from 2010 to 2014. Using a TMDN-DEA model, we calculate the overall efficiencies score and the technology gap ratios of each EU and non-EU countries from 2010 to 2014 in each and total stages. The first stage is production stage and the second stage is health treatment stage. Then we also calculate the efficiencies for the inputs and outputs of the production and health stage in EU countries and non-EU countries, including the non-renewable energy, renewable energy, PM2.5, $\mathrm{CO}_{2}$, labor, GDP, tuberculosis rate, children's mortality rate, adult's mortality rate, health expenditure efficiencies, and survival rate efficiencies. Finally, we have a generalization of the results of the study. First, the average overall efficiencies in EU countries were higher than in non-EU countries. Second, EU countries have higher energy efficiencies than non-EU countries and non-EU countries have higher health efficiencies than EU countries. Third, the renewable energy efficiencies were higher than the non-renewable energy efficiencies. The detail conclusions from analysis are as follows.

1. Average overall efficiencies each year in EU countries were higher than in non-EU countries from 2010 to 2014. An overall efficiency of 1 in all four years was achieved by Malta which are EU countries and Brunei, Japan, Iceland, Saudi Arabia, Singapore, and United States which are non-EU countries.

2. These countries where average overall efficiencies are lower in EU are all located in the east Europe, for example, Bulgaria, Hungary, Poland, Czech, Romania, Austria, Croatia, Latvia, Lithuania, and Slovak. The countries where average overall efficiencies are lower in non-EU are developing countries. For example, India, Vietnam, South Africa, Ukraine Brazil, Bangladesh, Belarus, Chile, China, Colombia, Iran, Morocco, Kazakhstan, Kenya, Malaysia, Mexico, Peru, Philippines, Thailand, Tunisia, and Turkey.

3. EU countries have higher energy efficiencies than non-EU countries and non-EU countries have higher health efficiencies than EU countries. The average overall efficiencies of EU countries are higher than those of non-EU countries each year from 2010 to 2014 in the first stage (production stage). But the average overall efficiencies of EU countries are lower than those of non-EU countries each year from 2010 to 2014 in the second stage (health treatment stage).

4. There is much more space to improve the healthy efficiencies for the countries in EU. The average overall efficiencies in the second stage are all lower than those in the first stage both for EU countries and for non-EU countries each year, especially it is obviously for EU countries.

5. EU countries have a bigger gap between group frontier (GF) and meta-frontier (MF) in the healthy treatment stage. Although the TGRs of EU countries were higher than the ones of non-EU countries in the first stage, the TGRs of EU countries were too low than the non-EU countries. Thus, the technical efficiency of the group frontier of non-EU countries is higher than EU countries.

6. The renewable energy efficiencies were higher obviously than the non-renewable energy efficiencies and PM2.5 efficiencies were higher obviously than the $\mathrm{CO}_{2}$ efficiencies for EU countries and non-EU countries. But there is much more space for the non-EU countries to improve the energy efficiencies of inputs and outputs.

7. There is much more space for the non-EU countries to improve the tuberculosis rate efficiencies and children's mortality rate efficiencies, and there are much more space for the EU countries to improve the health expenditure efficiencies and the adult's mortality rate efficiencies.

8. The children's mortality rate efficiencies were higher than the adult's mortality rate efficiencies for EU countries and non-EU countries. There are 19 countries where the children's mortality rate efficiencies were 1 , but there are 14 countries where the children's mortality rate efficiencies were 1 in all five years.

9. The health expenditure efficiencies in the EU countries are obviously lower than those in non-EU countries. In the non-EU, there are 9 countries where health expenditure efficiencies were 1, but there are 2 countries in EU. There are 13 countries where health expenditure efficiencies were 
below 0.1 in the non-EU countries, but there are 11 countries in EU. Most of countries where the health expenditure efficiencies were below 0.1 in the EU countries are high welfare countries, for example, Belgium, Denmark, France, UK, Iceland, Netherlands, Spain, and Portugal.

In theory, this paper has enough literature to prove the significance and value of our research. First of all, we applicate a modified meta dynamic network model with a production stage to analysis renewable and non-renewable energy efficiency. Second, we have a second health treatment stage to focus on health expenditure and the impact on survival rate of 65 years old, children's and adults' mortality rate in EU countries and non-EU countries. Through the conclusion of this paper, this paper puts forward the following practical and positive suggestions for the EU and non-EU countries.

- As we known from conclusions, the non-renewable energy efficiencies are much lower than the renewable energy efficiencies in the EU and non-EU countries. The government management in the EU and non-EU countries should be strengthened to reduce air pollutant and carbon dioxide emissions which are from the consumption of the non-renewable energy. Moreover, EU-ETS should play a greater role. The price of emission right has affected the production decision of enterprises. If enterprises do not take emission reduction measures, they need to bear more cost of emission reduction. This is conducive to the transformation of energy consumption of enterprises to renewable energy.

- Because the efficiencies of renewable energy are higher than ones of non-renewable, so it is more inclined to use renewable energy, especially clean energy in renewable energy, such as solar energy, wind energy, and so on. Further attention should be given to raise energy transformation to the clean energy in renewable energy. At the same time, the efficiency improvement of renewable energy is to improve the efficiency of energy management. The efficiency improvement of energy transmission and distribution management will enhance the utilization efficiency of new energy. EU countries and non-EU countries should encourage the application of new technologies in new energy development and energy management efficiency improvement.

- Because of the differences of the health efficiencies are serious among the non-EU countries and the health efficiencies in developing countries are lower than ones of developed countries. These developing countries should concentrate more on the health expenditure. Health expenditure is the basic social security. Non-EU governments should consider establishing corresponding laws and regulations to protect health expenditure.

- As we known from conclusions, the health expenditure efficiency of EU countries is even much lower than non-EU countries. Meanwhile, most of these EU countries are the high-welfare countries. These high-welfare countries in Western Europe should consider how to make full use of medical resources and improve medical efficiency. The government of high welfare countries should actively encourage new medical technology to improve health efficiency while ensuring health expenditure.

- The health efficiencies are low in the EU and non-EU countries, health expenditure efficiency should be improved. Especially in EU countries, there are too much space to reduce their adult's mortality rate. The prompt of health efficiency not only depends on the improvement of technology, but also the management efficiency of government in health expenditure.

Author Contributions: Conceptualization, Y.F. and X.Y.; methodology, Y.-h.C.; software, T.-H.C.; validation, Y.-h.C., T.-H.C. and Y.F.; formal analysis, Y.F. and X.Y.; investigation, X.Y.; resources, Y.-h.C. and T.-H.C.; data curation, X.Y.; writing—original draft preparation, Y.F.; writing—review and editing, X.Y., Y.-h.C. and T.-H.C.; visualization, T.-H.C.; supervision, Y.F.; project administration, Y.-h.C.; funding acquisition, Y.F.

Funding: This study was supported by the international innovation team program in philosophy and social sciences of Jilin university "China's foreign trade and financial cooperation under the BRI" (2019GJTD03) and the Major Projects of the Key Research Base of Humanities and Social Sciences of the Ministry of Education in Liaoning University "Transformation of Countries to Participate in the Construction of the Belt and Road and the Transformation of the International Structure" (LNUJD201705).

Conflicts of Interest: The authors declare no conflict of interest. 


\section{References}

1. The World Bank. Available online: https://data.worldbank.org.cn/indicator/NY.GDP.MKTP.CD (accessed on 8 August 2019).

2. European Court of Auditors. Available online: https://www.eca.europa.eu/en/Pages/ecadefault.aspx (accessed on 8 August 2019).

3. Sueyoshi, T.; Goto, M. Should the US clean air act include $\mathrm{CO}_{2}$ emission control? Examination by data envelopment analysis. Energy Policy 2010, 38, 5902-5911. [CrossRef]

4. Liou, J.L.; $\mathrm{Wu}$, P.I. Will economic development enhance the energy use efficiency and $\mathrm{CO}_{2}$ emission control efficiency? Expert Syst. Appl. 2011, 38, 12379-12387. [CrossRef]

5. Choi, Y.; Zhang, N.; Zhou, P. Efficiency and abatement costs of energy-related $\mathrm{CO}_{2}$ emissions in China: A slacks-based efficiency measure. Appl. Energy 2012, 98, 198-208. [CrossRef]

6. Zhang, N.; Choi, Y. Environmental Energy Efficiency of China's Regional Economies: A non-oriented slacks-based measure analysis. Soc. Sci. J. 2013, 50, 225-234. [CrossRef]

7. Yang, L.; Wang, K.L. Regional differences of environmental efficiency of China's energy utilization and environmental regulation cost based on provincial panel data and DEA method. Math. Comput. Model. 2013, 58, 1074-1083. [CrossRef]

8. Zhao, X.; Yin, H.; Zhao, Y. Impact of environmental regulations on the efficiency and $\mathrm{CO}_{2}$ emissions of power plants in China. Appl. Energy 2015, 149, 238-247. [CrossRef]

9. Yao, X.; Guo, C.; Shao, S.; Jiang, Z. Total-factor $\mathrm{CO}_{2}$ emission performance of China's provincial industrial sector:A meta-frontier non-radial Malmquist index approach. Appl. Energy 2016, 184, 1142-1153. [CrossRef]

10. Wang, J.; Zhao, T.; Zhang, X. Environmental assessment and investment strategies of provincial industrial sector in China-Analysis based on DEA model. Environ. Impact Assess. Rev. 2016, 60, 156-168. [CrossRef]

11. Qin, Q.; Li, X.; Li, L.; Zhen, W.; Wei, Y.M. Air emissions perspective on energy efficiency: An empirical analysis of China's coastal areas. Appl. Energy 2017, 185, 604-614. [CrossRef]

12. Sağlam, Ü. A two-stage data envelopment analysis model for efficiency assessments of 39 state's wind power in the United States. Energy Convers. Manag. 2017, 146, 52-67. [CrossRef]

13. Feng, C.; Zhang, H.; Huang, J.B. The approach to realizing the potential of emissions reduction in China: An implication from data envelopment analysis. Renew. Sustain. Energy Rev. 2017, 71, 859-872. [CrossRef]

14. Bi, G.B.; Song, W.; Zhou, P.; Liang, L. Does environmental regulation affect energy efficiency in China's thermal power generation? Empirical evidence from a slacks-based DEA model. Energy Policy 2014, 66, 537-546. [CrossRef]

15. Sun, M.; Wang, Y.; Shi, L.; Klemeš, J.J. Uncovering energy use, carbon emissions and environmental burdens of pulp and paper industry: A systematic review and meta-analysis. Renew. Sustain. Energy Rev. 2018, 92, 823-833. [CrossRef]

16. Zeng, S.; Nan, X.; Liu, C.; Chen, J. The response of the Beijing carbon emissions allowance price (BJC) to macroeconomic and energy price indices. Energy Policy 2017, 106, 111-121. [CrossRef]

17. Li, M.; Mi, Z.; Coffman, D.; Wei, Y.M. Assessing the policy impacts on non-ferrous metals industry's $\mathrm{CO}_{2}$ reduction: Evidence from China. J. Clean. Prod. 2018, 192, 252-261. [CrossRef]

18. Zeng, S.; Jiang, C.; Ma, C.; Su, B. Investment Efficiency of the New Energy Industry in China. Energy Econ. 2018, 70, 536-544. [CrossRef]

19. Bampatsou, C.; Papadopoulos, S.; Zervas, E. Technical efficiency of economic systems of EU-15 countries based on energy consumption. Energy Policy 2013, 55, 426-434. [CrossRef]

20. Cucchiella, F.; D'Adamo, I.; Gastaldi, M.; Miliacca, M. Efficiency and allocation of emission allowances and energy consumption over more sustainable European economies. J. Clean. Prod. 2018, 182, 805-817. [CrossRef]

21. Gomez-Calvet, R.; Conesa, D.; Gomez-Calvet, A.R.; Tortosa-Ausina, E. Energy efficiency in the European Union: What can be learned from the joint application of directional distance functions and slacks-based measures? Appl. Energy 2014, 132, 137-154. [CrossRef]

22. Dumana, Y.S.; Kasman, A. Environmental technical efficiency in EU member and candidate countries: A parametric hyperbolic distance function approach. Energy 2018, 147, 297-307. [CrossRef] 
23. Cecchini, L.; Venanzi, S.; Pierri, A.; Chiorri, M. Environmental efficiency analysis and estimation of $\mathrm{CO}_{2}$ abatement costs in dairy cattle farms in Umbria (Italy): A SBM-DEA model with undesirable output. J. Clean. Prod. 2018, 197, 895-907. [CrossRef]

24. Suzuki, S.; Nijkamp, P. EU countries appear to exhibit generally a higher efficiency than APEC and ASEAN countries. Energy Policy 2016, 88, 100-112. [CrossRef]

25. Moutinho, V.; Madaleno, M.; Macedo, P. Efficiency in the European agricultural sector: Environment and resources. Environ. Sci. Pollut. Res. 2018, 25, 17927-17941. [CrossRef] [PubMed]

26. Reinhard, S.; Lovell, C.; Thijssen, G.J. Environmental efficiency with multiple environmentally detrimental variables; estimated with SFA and DEA. Eur. J. Oper. Res. 2000, 121, 287-303. [CrossRef]

27. Robaina-Alves, M.; Moutinho, V. Decomposition of energy-related GHG emissions in agriculture over 1995-2008 for European countries. Appl. Energy 2014, 114, 949-957. [CrossRef]

28. Toma, P.; Miglietta, P.P.; Zurlini, G.; Valente, D.; Petrosillo, I. A non-parametric bootstrap-data envelopment analysis approach for environmental policy planning and management of agricultural efficiency in EU countries. Ecol. Indic. 2017, 83, 132-143. [CrossRef]

29. Vlontzos, G.; Niavis, S.; Manos, B. A DEA approach for estimating the agricultural energy and environmental efficiency of EU countries. Renew. Sustain. Energy Rev. 2014, 40, 91-96. [CrossRef]

30. Cohen, A.J.; Brauer, M.; Burnett, R.; Anderson, H.R.; Frostad, J.; Estep, K.; Balakrishnan, K.; Brunekreef, B.; Dandona, L.; Dandona, R.; et al. Estimates and 25-year trends of the global burden of disease attributable to ambient air pollution: An analysis of data from the Global Burden of Diseases Study 2015. Lancet 2017, 389, 1907-1918. [CrossRef]

31. Wang, Y. The analysis of the impacts of energy consumption on environment and public health in China. Energy 2010, 35, 4473-4479. [CrossRef]

32. Fischer, P.H.; Marra, M.; Ameling, C.B.; Hoek, G.; Beelen, R.; de Hoogh, K.; Breugelmans, O.; Kruize, H.; Janssen, N.A.H.; Houthuijs, D. Air pollution and mortality in seven million adults: The Dutch Environmental Longitudinal Study (DUELS). Environ. Health Perspect. 2015, 123, 697-704. [CrossRef]

33. Yang, B.Y.; Qian, Z.M.; Vaughn, M.G.; Nelson, E.J.; Dharmage, S.C.; Heinrich, J.; Lin, S.; Lawrence, W.R.; Ma, H.; Chen, D.H.; et al. Is prehypertension more strongly associated with long-term ambient air pollution exposure than hypertension? Findings from the 33 Communities Chinese Health Study. Environ. Pollut. 2013, 229, 696-704. [CrossRef] [PubMed]

34. Li, L.; Lei, Y.; Wu, S.; Huang, Z.; Luo, J.; Wang, Y.; Chen, J.; Yan, D. Evaluation of future energy consumption on PM2.5 emissions and public health economic loss in Beijing. J. Clean. Prod. 2018, 187, 1115-1128. [CrossRef]

35. Liu, L.; Wang, K.; Wang, S.; Zhang, R.; Tang, X. Assessing energy consumption, $\mathrm{CO}_{2}$ and pollutant emissions and health benefits from China's transport sector through 2050. Energy Policy 2018, 116, 382-396. [CrossRef]

36. Dauchet, L.; Hulo, S.; Cherot-Kornobis, N.; Matran, R.; Amouyel, P.; Edmé, J.L.; Giovannelli, J. Short-term exposure to air pollution: Associations with lung function and inflammatory markers in non-smoking, healthy adults. Environ. Int. 2018, 121, 610-619. [CrossRef] [PubMed]

37. Carlton, E.J.; Barton, K.; Shrestha, P.M.; Humphrey, J.; Newman, L.S.; Adgate, J.L.; Root, E.; Miller, S. Relationships between home ventilation rates and respiratory health in the Colorado Home Energy Efficiency and Respiratory Health (CHEER) study. Environ. Res. 2019, 169, 297-307. [CrossRef] [PubMed]

38. Shen, F.; Ge, X.; Hu, J.; Nie, D.; Tian, L.; Chen, M. Air pollution characteristics and health risks in Henan Province, China. Environ. Res. 2017, 156, 625-634. [CrossRef]

39. Ljungman, P.L.S.; Li, W.; Rice, M.B.; Wilker, E.H.; Schwartz, J.; Gold, D.R.; Koutrakis, P.; Benjamin, E.J.; Vasan, R.S.; Mitchell, G.F.; et al. Long-and short-term air pollution exposure and measures of arterial stiffness in the Framingham Heart Study. Environ. Int. 2018, 121, 139-147. [CrossRef]

40. Torres, P.; Ferreira, J.; Monteiro, A.; Costa, S.; Pereira, M.C.; Madureira, J.; Mendes, A.; Teixeira, J.P. Air pollution: A public health approach for Portugal. Sci. Total Environ. 2018, 643, 1041-1053. [CrossRef]

41. Chen, C.; Li, C.; Li, Y.; Liua, J.; Meng, C.; Han, J.; Zhang, Y.; Xua, D. Short-term effects of ambient air pollution exposure on lung function: A longitudinal study among healthy primary school children in China. Sci. Total Environ. 2018, 645, 1014-1020. [CrossRef]

42. Knibbs, L.D.; de Waterman, A.M.C.; Toelle, B.G.; Guo, Y.; Denison, L.; Jalaludin, B.; Marks, G.B.; Williams, G.M. The Australian Child Health and Air Pollution Study (ACHAPS): A national population-based cross-sectional 
study of long-term exposure to outdoor air pollution, asthma, and lung function. Environ. Int. 2018, 120, 394-403. [CrossRef]

43. Roberts, S.; Arseneault, L.; Barratt, B.; Beevers, S.; Danese, A.; Odgers, C.L.; Moffitt, T.E.; Reuben, A.; Kelly, F.J.; Fisher, H.L. Exploration of $\mathrm{NO}_{2}$ and PM2.5 air pollution and mental health problems using high-resolution data in London-based children from a UK longitudinal cohort study. Psychiatry Res. 2019, 272, 8-17. [CrossRef] [PubMed]

44. Zaman, K.; Abdullah, A.B.; Khan, A.; bin Mohd Nasir, M.R.; Hamzah, T.A.A.T.; Hussain, S. Dynamic linkages among energy consumption, environment, health and wealth in BRICS countries: Green growth key to sustainable development. Renew. Sustain. Energy Rev. 2016, 56, 1263-1271. [CrossRef]

45. Farrell, M.J. The Measurement of Productive Efficiency. J. R. Stat. Soc. Ser. A (Gen.) 1957, 120, $253-290$. [CrossRef]

46. Charnes, A.; Cooper, W.W.; Rhodes, E. Measuring the Efficiency of Decision Making Units. Eur. J. Oper. Res. 1978, 2, 429-444. [CrossRef]

47. Banker, R.D.; Charnes, A.; Cooper, W.W. Some Models for Estimating Technical and Scale Inefficiencies in Data Envelopment Analysis. Manag. Sci. 1984, 30, 1078-1092. [CrossRef]

48. Färe, R.; Grosskopf, S.; Whittaker, G. Network DEA. Modeling Data Irregularities and Structural Complexities in Data Envelopment Analysis; Springer: Berlin, Germany, 2007; pp. 209-240.

49. Tone, K.; Tsutsui, M. Network DEA: A slacks-based measure approach. Eur. J. Oper. Res. 2009, 197, $243-252$. [CrossRef]

50. Tone, K.; Tsutsui, M. Dynamic DEA: A slacks-based measure approach. Omega 2010, 38, 145-156. [CrossRef]

51. Tone, K.; Tsutsui, M. Dynamic DEA with network structure: A slacks-based measure approach. Omega 2013, 42, 124-131. [CrossRef]

52. O'Donnell, C.J.; Rao, D.P.; Battese, G.E. Metafrontier frameworks for the study of firm-level efficiencies and technology ratios. Empir. Econ. 2008, 34, 231-255. [CrossRef]

53. Hu, J.L.; Wang, S.C. Total-factor energy efficiency of regions in China. Energy Policy 2006, 34, 3206-3217. [CrossRef]

54. World Health Organization. Global Tuberculosis Control Report. 2018. Available online: https://www.who. int/ (accessed on 1 August 2019).

(C) 2019 by the authors. Licensee MDPI, Basel, Switzerland. This article is an open access article distributed under the terms and conditions of the Creative Commons Attribution (CC BY) license (http://creativecommons.org/licenses/by/4.0/). 